\title{
هرمنيوطيقا قضايا العقيدة في الفكر العربي الحديث: دراسة تحليليّة
}

HERMENEUTICS OF CREED'S ISSUES IN THE MODERN ARAB THOUGHT: AN ANALYTICAL STUDY

\section{Abdullah Awad al-Ajmi}

Department of Creed \& Daawa. Faculty of Sharia \& Islamic Studies. P.O. Box 5969, Safat - 13060.

Kuwait University. Kuwait.

Email: abdallah.alajmi@gmail.com

\begin{abstract}
Khulasah
Istilah 'hermeneutik' muncul dalam pemikiran Barat ketika mereka mencari metode yang betul untuk memahami dan berinteraksi dengan teks. Sebahagian pemikir Arab meyakini metode ini sebagai satusatunya pendekatan untuk memahami teks Shariah dan perkara-perkara agama serta dalam masa yang sama dilihat selaras dengan pemikiran rasional dan sains empirikal. Kajian ini bertujuan menjelaskan pemikiran Arab moden berkenaan hermeneutik dan usaha mereka mengaplikasikan metode ini kepada teks Shariah serta persoalan keyakinan asas seperti ciri-ciri ketuhanan, kenabian serta aspek-aspek metafizik yang tidak terjangkau oleh akal seperti yang terdapat dalam al-Qur'an dan hadis.
\end{abstract}

Kata kunci: hermenuitik; pemikiran Barat; teks Syariah; pemikiran Arab moden.

\footnotetext{
Abstract

The term 'hermeneutics' appears in Western thought when they seek the right method to understand and interacting with the text. Some Arab thinkers believe this method as the only approach to understand Shariah texts and religious matters while at the same time seen in line with rational thinking and empirical science. This study is aimed at explaining the modern
} 
Arabic thinking regarding hermeneutics and their efforts to apply this method to Shariah texts as well as basic beliefs such as divine, prophecy and metaphysical aspects that are not reachable to the mind as found in the Qur'an and the Hadith.

Keywords: hermeneutics; the Western thought; Sharia texts; the modern Arab thought.

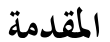

فإن من خصائص العقيدة الصحيحة - كما هو متقرر - سلامة مصدرها؛ وذلك باعتمادها بشكل رئيس على الوحي المتضمن لما جاء في القرآن وسنة النبي (صلى الله عليه وسلم)؛ فجلٌٌ مسائلها غيبية، والغيب يعتمد على التسليم والتصديق المطلق لله تعالى ولرسوله (صلى الله عليه وسلم)، وهذا من صفات المؤمنين الذين أثنى عليهم الله بقوله:

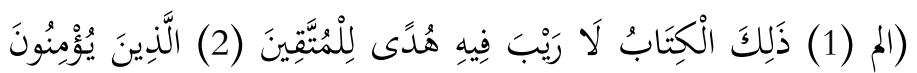
بِالْغَيْبِ...1)

ومع ذلك فقد خاض بعض الناس في مسائل الغيب بدون وجه

حق معرضين عن الوحي الذي جاء به الله تعالى، ومبتعدين عن فهم النبي (صلى الله عليه وسلم) وأصحابه وأئمة المسلمين له؛ بتقديم عقولمم وأفهامهم القاصرة وعلومهم التجريبية عليها، فنتج عن ذلك اختلافهم في فهمها، وتعدّد مناهجهم في عرضها، وسبب ذلك كله تأثرهم بالمناهج الغربية والفلسفات المادية وتطبيقها على النصوص الشرعية

${ }^{1}$ Al-Baqarah 2:1-2. 
Abdullah Awad, "Hermenuitics of Creed Issue," Afkār Vol. 19 Issue 2 (2017):

(القرآن والسنة)، وعلى مسائل العقيدة؛ لاعتقادهم بأها تتعارض مع

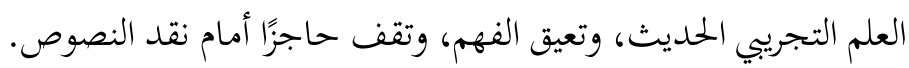

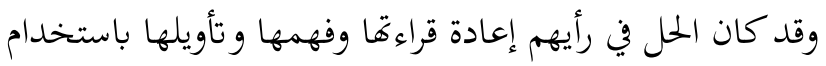

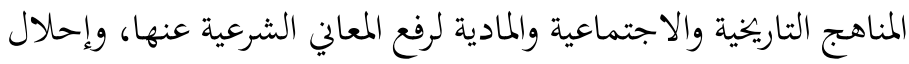

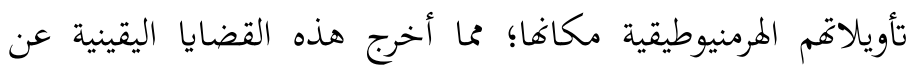
مضمونا، وفرّغها من محتواها، فجاءت على غير مراد الله تعالى.

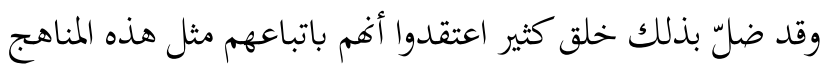

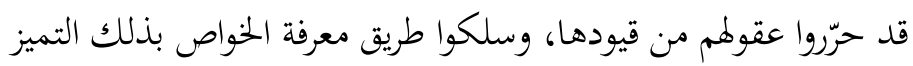

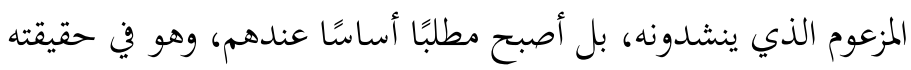

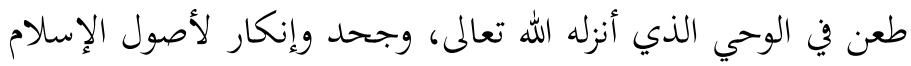
التي جاء بها الأنبياء جميعًا.

ومن هنا جاءت فكرة هذا البحث الذي عنونته بـ (هرمنيوطيقا

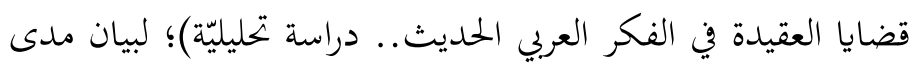

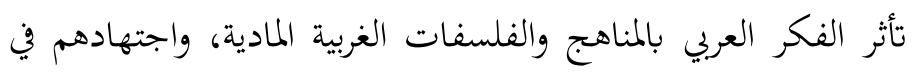
تطبيقها على النصوص الشرعية وقضايا الدين الرئيسة. أهداف البحث

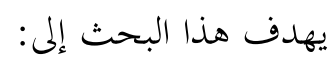
1- بيان ماهية الهرمنيوطيقا في الوسط الذي نشأت فيه، وتوضيح معناها في الفكر العربي الحديث. 
Abdullah Awad, "Hermenuitics of Creed Issue," Afkār Vol. 19 Issue 2 (2017):

2- بيان مدى تأثر الفكر العربي الحديث بمناهج الهرمنيوطيقا،

$$
\text { وتطبيقها على النصوص الشرعية. }
$$

3- الكشف عن كيفية امتداد هذا التأثير ليشمل قضايا العقيدة

$$
\text { ومسائل الدين الرئيسة. }
$$

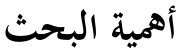

1- انتشار هذه الأفكار في الأوساط المثقفة وفي وسائل الإعلام

$$
\text { المختلفة. }
$$

2- محاولة أسلمة هذه المناهج من خلال البحث عن أصول

$$
\text { مزعومة لها في التاريخ الإسلامي. }
$$

3- اعتقاد أصحاب هذه المناهج بأغها السبيل الوحيد لفهم

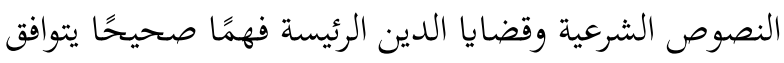

$$
\text { مع العقل والعلوم التجريبية. }
$$

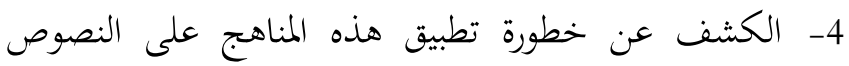

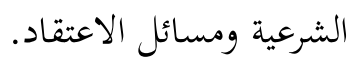

\section{منهج البحث}

اعتمدت في هذه الدراسة المنهج التحليلي الوصفي، وذلك بعرض هذه

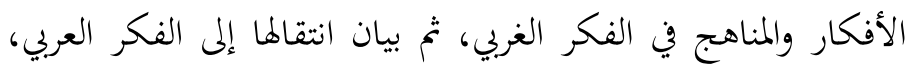

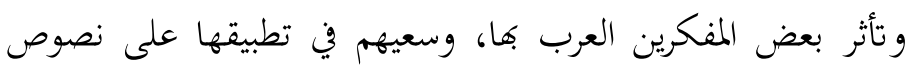
الوحي وقضايا العقيدة، مبينًا منهجهم في هذه المحاولات وطريقة تطبيقها

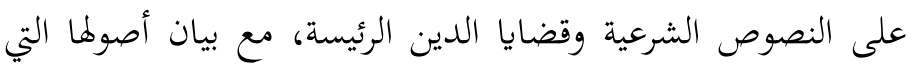


Abdullah Awad, "Hermenuitics of Creed Issue," Afkār Vol. 19 Issue 2 (2017):

استمدت منها، ولم أتعرض لنقد الأفكار والرد عليها؛ لاعتقادي أن

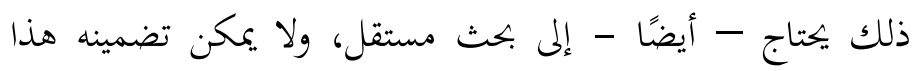
البحث؛ لطبيعة هذه البحوث - كما هو معلوم - وتقييدها بصفحات محددة.

\section{خطة البحث}

اقتضت طبيعة البحث أن أقسمه إلى: مقدمة، وتمهيد، وأربعة مباحث، أبحة

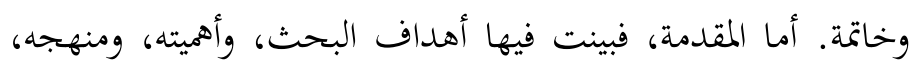

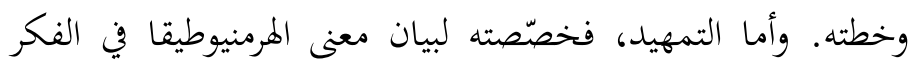

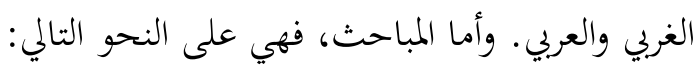
المبحث الأول: هرمنيوطيقا النص الشرعي. المبحث الثاني: هرمنيوطيقا قضايا الألوهية. المبحث الثالث: هرمنيوطيقا قضايا النبوات. المبحث الرابع: هرمنيوطيقا قضايا السمعيات. وأما الخاتمة، فذكرت فيها أهم النتائج التي توصلت إليها خلال البحث.

\section{معنى الهرمنيوطيقا}

كثرت معاني الهرمنيوطيقا (hermeneutics) وتباينت تعريفاها، فهي تأتي أحيانًا بمعنى التفسير الحرين، ويمكن اعتبار هذا المعنى أقدم معانيها، وسبب ذلك كوها بدأت كعملية تفسير للنصوص المقدسة، ويدل عليه 
Abdullah Awad, "Hermenuitics of Creed Issue," Afkār Vol. 19 Issue 2 (2017):

أصل الكلمة الذي اشتقت منه في اللغة اليونانية وهو: (hermeneuin)، ومعناه: يفسّر، ومن الاسم: (hermeneia) بمعنى: التفسير. وقد استمر هذا المعنى إلى ما يقارب القرن العشرين على الرغم

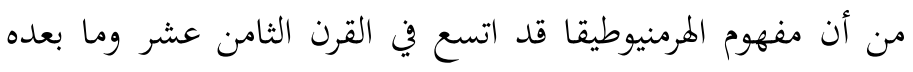

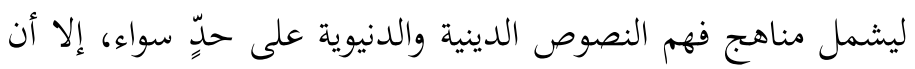

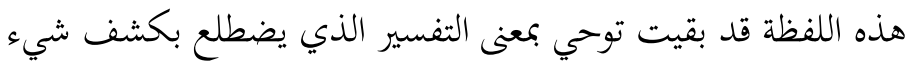
ما خبيء ومستور وسرّيٍّ، ويندّ عن الفهم العادي والقراءة المعهودة. 2

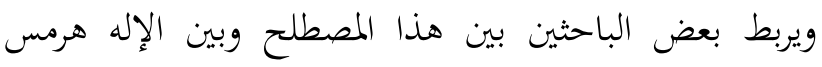

(Olympus) عند اليونانيين؛ وهو رسول آلهة أوليمبوس (Hermes)

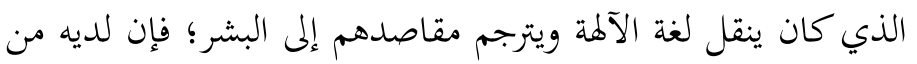

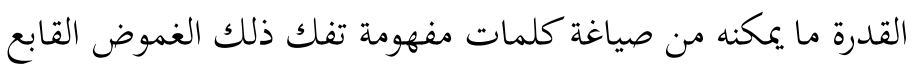
وراء القدرة البشرية. 3 ومن هنا فالتفسير هو أحد العناصر الأساسية الملازمة لتكوين الهرمنيوطيقا، وهو من أكثر الأفعال المعبرة عن جوهر التفكير الإنساني،

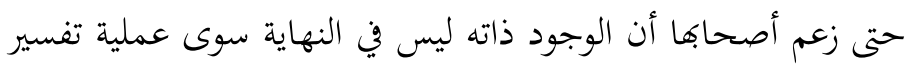
مستمرة، ويمكن اعتبار التفسير المعنى التقليدي لهذا المصطلح.

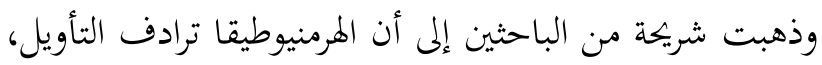
ويستدرك بعضهم فيقول هي مقاربة للتأويل، غير أن لفظة التأويل

2 See: `Ādil Muștafāā, Fahm al-Fahm Madkhal ila al-Hermeneuțiqqā (Cairo: Ruaya al-Nashr wa al-Tawzi', 2007), 26.

${ }^{3}$ Ibid., 24. 
Abdullah Awad, "Hermenuitics of Creed Issue," Afkār Vol. 19 Issue 2 (2017):

يقابلها في الفرنسية كلمة: anagogic، وفي الإنجليزية: interpretation، في حين تبقى كلمتا hermeneutics hermeneutique قائمتين بذاهما في هاتين اللغتين 4، وهذا يعني أن لفظة التأويل ليست مطابقة لهذا المصطلح، وإن كان التأويل من العناصر الأساسية فيه؛ والسبب في ذلك كون التأويل يبحث في الدلالة، بينما الهرمنيوطيقا تبحث في آليات الفهم؛ ولذا فالتركيز فيها على القارئ، أما التأويل فالتركيز فيه على القائل 5

وفي مقارنة بين التفسير والتأويل والهرمنيوطيقا، يذكر د. حسن حنفي أن الهرمنيوطيقا تعني علم التأويل والتفسير دون وضع فروق بينهما، ثم يستدرك فيقول: إلا إذا قلنا إن التفسير يظل هو التفسير الذي يعتمد على اللغة وأسباب النزول دون أن ندخل في الباطنية، ودون أن ندخل في مستويات أعماق النص. أما الهرمنيوطيقا أي علوم التأويل، فهذه تتجاوز مستوى علوم اللغة ومستوى الواقع والعالم إلى مستوى المعاني الباطنية للنص وأبعاده المختلفة، وهذا التأويل ينطبق أكثر على الهرمنيوطيقا؛ لأن التأويل يتضمن الأبعاد الباطنية للنص إذا ما عاشه الشعور، في حين أن التفسير هو مجرد ضبط لغوي وفهم عن طريق مباحث الألفاظ 6.

${ }^{4}$ See: Yāsīn Bāhì, al-Ta'wīl wa Falsafah al-Tawāṣul (Jordan: al-Kutub al-Hadith, 2016), 6.

${ }^{5}$ Sízā Qāsim, al-Qārì' wa al-Naṣ (Cairo: al-Majlis al-'A lā al-Thaqāfah, 2002), 11.

6 Hasan Hanafī, "al-Hermeneuțiqā wa 'Ulūm al-Ta'wìl," Majallah Qaḍāyā Islāmiyyah Mu`āṣarah, vol. 19, 89. 
ويفضل شوقي الزين صيغة "فن التأويل" فيقول: "بحدر الإشارة

إلى أننا نبتغي صيغة "فن التأويل" لترجمة كلمة hermeneutique تمييزًا لها عن التأويل بمعنى interpretation"، فيبتعد شوقي قليلاً ليعطي المفهوم الأوسع لدلالة المصطلح؛ حيث ينقله إلى الفن ليكون تعبيرًا عن المعاني الجمالية الحفية في إنتاج الدلالة كما يعتقد. 7 بينما يرى نصر حامد أبو زيد أن الهرمنيوطيقا هي مجموعة القواعد والمعايير التي يجب أن يتبعها المفسر لفهم النص الديني، وهي بذذا المعنى تختلف عن التفسير الذي يشير إليه لفظ: exegesis؛ لأن هذا اللفظ يشير إلى التفسير نفسه في تفاصيله التطبيقية، بينما المصطلح الأول يشير إلى نظرية التفسير هـئ. ويمكن الاستدلال لما سبق بما ذكره غادمير من أن كلمة

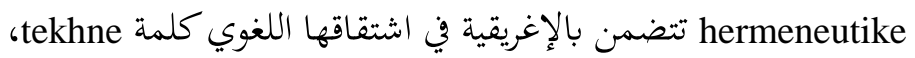
التي تشير إلى الفن بالمعنى الاستعمالي التقني لآليات ووسائل لغوية ومنطقية وتصويرية واستعمالية ورمزيةج.9 لذلك يمكننا القول بأها طريقة منهجية في القراءة تُعنى بقواعد تفسير و تأويل النصوص الدينية المقدسة ابتداء، ثم توسّع مدلولها ليشمل

7 Ismā̄ì Niqāz, Manāhij al-Ta'wìl fī al-Fikr al-Ușūìi: Dirāsah Tah̆lïliyyah wa Naqdiyyah Muqāranah li Manāhij al-Ta'wīliyyah alMu āṣarah (Beirut: Markaz Naml li al-Buhūth wa al-Dirāsāt, 2017). 145.

${ }^{8}$ Nașr Ḥāmid Abū Zayd, Ishkāliyyāt al-Qirā'ah wa Āliyāt al-Ta'wìl (Beirut: al-Markaz al-Thaqāfī al-'Arabì, 2014), 13.

${ }^{9}$ Ghādmìr Hanz, Falsafah al-Ta'wìl, trans. Muhammad Shauqi al-Zayn (Beirut: Manșūrah, 2000), 62. 
Abdullah Awad, "Hermenuitics of Creed Issue," Afkār Vol. 19 Issue 2 (2017):

النظرية المنهجية لجميع أنواع التأويل؛ كالتأويل الفيلولوجي، والعلمي،

$$
\text { والإنساني، والوجودي. }
$$

ويرجح بعضطم هذا المعنى على المعنى الذي قبله معلّلَ ذلك بكون التأويل مصطلحًا إجرائيَّا يتعامل مع النص في ضوء آليات معينة، فالهدف من التأويل هو الكشف عن المعاني بعد إزاحة ستار الظاهر عنها. أما دراسة الأصول المعرفية للتأويل كنظرية، فهي دراسة خارج إطار التأويل، وإنما تؤسس له كنظرية، والهرمنيوطيقا بعَِّّها نظرية التأويل تبحث في معرفة التأويل لا من حيث هو بحث إجرائي، وإنما نظرية ذات بُعدٍ أبستمولوجي تتعلق بالتنظير للعملية التأويلية أو التفسيرية أو

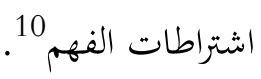

ومع تطور النظرية النسبية أصبحت الهرمنيوطيقا تختص بـ(فن الفهم)، وهو المعنى الذي أسّس له شلاير ماخر، الذي يعدُّ أبا التأويلية الحديثة، وأصبح فن الفهم أو فن التأويل لا يقتصر على النصوص المقدسة فحسب، بل يتعدى ذلك إلى النصوص البشرية، وهذا المعنى هو الأكثر استعمالًا في المجالات الفلسفية والأدبية والفنية، وهو المتداول في الهرمنيوطيقا الحديثة والمعاصرة. فعلى يد "شلاير ماخر تخلّت الهرمنيوطيقا عن مهمتها الأولية المتمثلة في متابعة المعنى؛ لتصب جلّ اهتمامها على وضع القوانين والمعايير التي تضمن الفهم المناسب للنصوص، أيًّا كانت هذه

${ }^{10}$ Muhammad `Alī al-Husaynī, Abistemū lüjiyā al-Ta’wìl (Beirut: Dār alRafídayn, 2016), 108. 
Abdullah Awad, "Hermenuitics of Creed Issue," Afkār Vol. 19 Issue 2 (2017):

النصوص"11، وبرغم هذا المفهوم الواسع الذي أوجده شلاير ماخر، فإذا تظل بعيدة عن دائرة البحث الفلسفي، في الوقت الذي تقترب فيه من طبيعة الأبحاث المنهجية التي تحاول إخراج الإنسان من دائرة

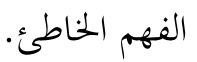

والواقع أن شلاير ماخر أعطى تصوّرًا جديدًا للهرمنيوطيقا، فأصبحت تُعنى بعلم الفهم أو فن الفهم، ويتضمن هذا التصور نقدًا جذريًّ لوجهة النظر الفيلولوجية (الفقهية اللغوية)؛ لأنه يسعى إلى بحاوز مفهوم التأويل على أنه مجموعة القواعد المترابطة نسقيَّا، أي جعل التأويل علمًا يصف الشروط اللازمة للفهم في أي حوار كان، بعد أن كانت مقتصرة على النصوص الكاسيكية الإغريقية واللاتينية والنصوص لئم المقدسة، وهي بهذا دراسة تتعلق بالفهم ذاته 12.

ويعمد دلتاي إلى جعل الهرمنيوطيقا الأساس الذي تقوم عليه جميع مباحث العلوم الروحية الإنسانية، وهي - عنده - عملية تختلف جوهريًّا عن الفهم العلمي للعالم الطبيعي؛ ذلك أن ما نقوم به في العملية

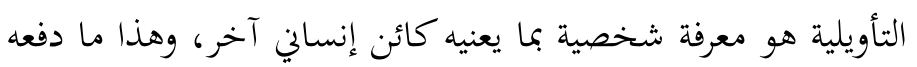
لانتقاد مقولات كانط التي من خلالما دُرست الأفعال الإنسانية، فاستبدلها بمقولات الحياة، ومن ثم فالمنهج الذي يصلح لتفسير الطبيعة

11 'Abd al-Karīm Sharafī, Min Falsafāt al-Ta'wīl ila Naẓariyyāt alQirā'ah (Beirut: al-Dār al-`Arabiyyah li al-`Ulūm, n.d), 25.

12 Rā'id al-'Awawdah, Falsafah al-Ta'wìl al-Tārikhī (Jordan: Alam alKutub al-Hadithah, 2016), 26. 
Abdullah Awad, "Hermenuitics of Creed Issue," Afkār Vol. 19 Issue 2 (2017):

غير المنهج الذي يصلح لفهم الفعل البشري؛ فالتفسير هو فعل خارجي لظواهر الطبيعة، بينما الفهم هو فعل داخلي لبواطن الكائن البشري 13. وأما هيدجر، فيُوغل في الاتجاه الفلسفي؛ إذ تناول الوجود اليومي الإنساني في العالم في كتابه "الوجود والزمان"، وأطلق على التحليل الذي قدمه اسم: الهرمنيوطيقا، واستعمل المنهج الفينومينولوجي في هذا التقديم؛ فالهرمنيوطيقا لا تشير عنده إلى علوم أو قواعد تأويل النصوص، ولا إلى منهج الرُوحيّة الإنسانيّة، وإنما تشير إلى تبيان فينومينولوجي للوجود الإنسائ ذاته، والفهم الوجودي، ويشير مفهومه هذا إلى أن إن إن الفهم والتأويل هما طريقان أو أسلوبان لوجود الإنسان، فليس الفهم شيئًا يفعله الإنسان، بل هو شيء يكونه، ومن ثم يكتشف التأويل عنده، وهذا يعني أن الهرمنيوطيقا أصبحت موصولة بالأبعاد الأنطولوجية للفهم، ومتوحدة في الوقت نفسه مع الصنف الخاص من الفينومينولوجيا الذي جاء بها هيدجر.

ويكمل غادمير هذا الاتجاه، فيفرق بين التأويل القديم والمعاصر؛

إذ الأخير أعطى القارئ المؤوّل دورًا كبيرًا، وهو بهذا ينتقل من المنهج إلى الحقيقة لتصبح علاقة التجربة التأويلية بالحقيقة هي علاقة إيضاح وكشف، أي حقيقة محايثة للتجربة وملازمة للتصور والممارسة، فالهرمنيوطيقا - عنده - عبارة عن نظرية في التأويل بمعنى تأمل فلسفي

${ }^{13}$ Bobner Rodger, al-Falsafah al-Almāniyyah al-Hadithah, trans. Fu'ad Kāmil (Cairo: Dār al-Thaqāfah li al-Nashr, n.d), 48.

${ }^{14}$ Aḥmad Zāyid, al-Hermenuitiqā wa Ishkāliyyāt al-Ta'wīl (Qatar: Qatar University, 1991), 165. 
Abdullah Awad, "Hermenuitics of Creed Issue," Afkār Vol. 19 Issue 2 (2017):

وتفكير فينومينولوجي حول نشاط عملي يتخذ طابع التفسير أو

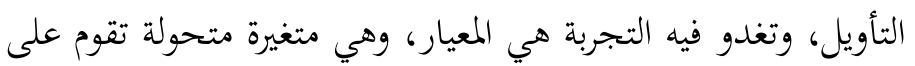

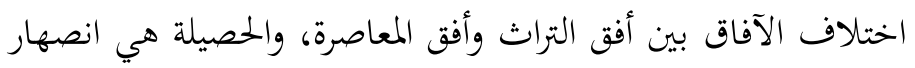

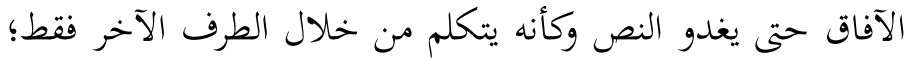

ومن هنا يمكننا القول إن الهرمنيوطيقا على نوعين:

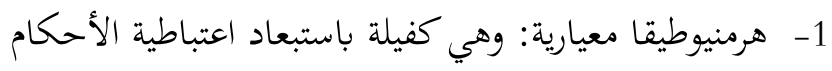

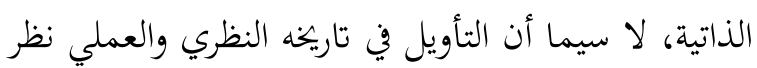

إليه على أساس أنه اعتباطي، ويخضع لاعتبارات ذاتية

وتصورات الأحكام الذاتية.

2- هرمنيوطيقا فلسفية: وهي تنتقد الطابع المعياري للهرمنيوطيقا

السابقة، وتدعو إلى تفكير فلسفي ونقدي حول ظاهرة

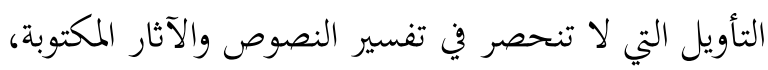

بل تحدد مستويات وجودنا في العالم التاريخي والأنطولوجي.

وهذا التوجه النقدي عنده يمكن وضعه ضمن إطار الاشتغال الفلسفي الفينومينولوجي الذي يتجه نخو انتقاد العلوم الطبيعية، ويُعنى

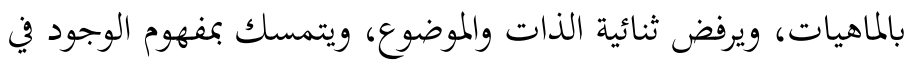
العالم.

${ }^{15}$ Jadmir, al-Haqiqah wa al-Manhaj, terj. Hasan Nazim and `Ali Șaliḥ (Dār Uyya, 2007), 510. 
Abdullah Awad, "Hermenuitics of Creed Issue," Afkār Vol. 19 Issue 2 (2017):

وأما بول ريكور، فقد شهدت الهرمنيوطيقا على يديه تغيرات

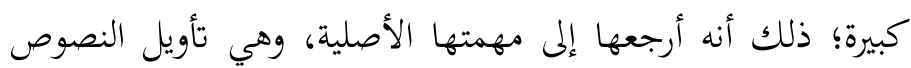

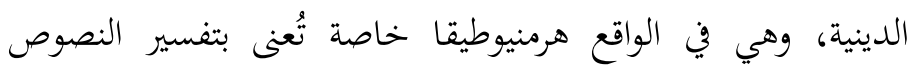

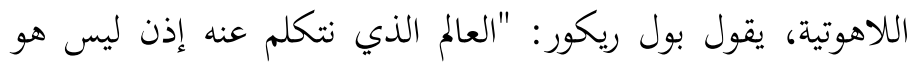

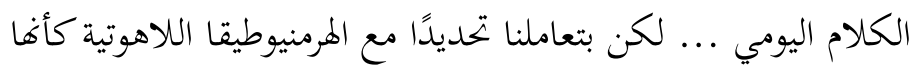

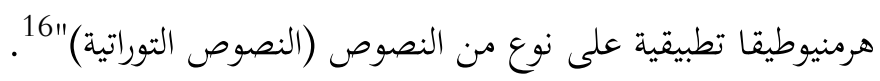

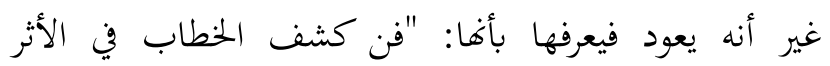
الأدبي"17، ومعنى هذا أنه يقسمها إلى نوعين: هرمنيوطيقا فلسفية، وهرمنيوطيقا توراتية، ويرى أن هناك علاقة تضمين بين النوعين، مؤكدًا

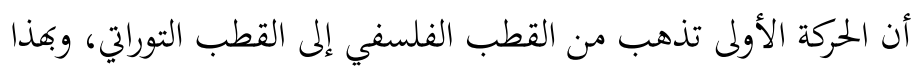

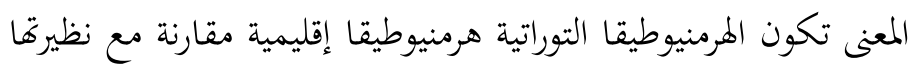
الفلسفية تكونت في الهرمنيوطيقا العامة، وأكد على تبعية الهرمنيوطيقا التوراتية للفلسفية بالتعامل معها على أها هرمنيوطيقا تطبيقية، وكأفا منظمتها.

وبتحر الإشارة هنا إلى أن تلميذه حسن حنفي خالفه في هذا التقسيم، ورأى أها تنقسم إلى: هرمنيوطيقا عامة، وهرمنيوطيقا مقدسة؛ إنى تلفيل

16 Paul Ricour, Min al-Nas ila al-Fi'l Abhāth al-Ta'wìl, trans. Muḥammad Barrada and Ḥasan Burqia (Cairo: al-Dirāsāt wa alBuhūth al-Insāniyyah al-Ijtimā̄iyyah, 2001), 88.

${ }^{17}$ Ibid., 85.

${ }^{18}$ Ibid., 91. 
فالأولى تضع قواعد عامة لتفسير أي نص، والأخرى تضع القواعد الخاصة لتفسير النصوص الدينية والكتب المقدسة وحدها. 19 يظهر محا سبق الاختلاف والتفاوت في بيان ماهيّة هذا المصطلح وحقيقته، والسبب الرئيس في ذلك هو التطورات التاريخية الجذرية التي مرّ بها المصطلح منذ نشأته، وتعدد الفلسفات الغربية التي بكثت مضامينه وجعلته يتجاوز المعنى الحرفي والدلالة الشكلية إلى دائرة معرفية ذات طابع استقلالي خاص، حتى صار مشروعًا فلسفيًّا في مجال نقد النصوص بل والحياة، وهذا الأمر جعل من الصعوبة بمكان إيجاد مرادف له في الثقافة العربية الإسلامية، ولذا "نجد كثيرً من الباحثين يُفضّلون إبقاء المصطلح على طبيعته الأساسية دون أن يترجم لأي مصطلح مقابل، وذلك بناءً على أن الهرمنيوطيقا وما تحمله من مخزون دلالي لا يوجد لها بالفعل ما يقابلها في الثقافة الإسلامية والعربية" 20. بينما يرى بعضهم إطلاق لفظ (التأويليات) ليضاهي به المصطلح الأجنبي، وعبر عنه بصيغة الجمع لكثرة التحاهاتا ومحاورها والحيز المعرفي الذي تشغله 21، ويرى البعض الآخر أن لفظ (التأويلية) هو الأنسب دون غيره؛ لأن مصطلح الهرمنيوطيقا لا يبتعد في مفهومه ودلالته عن مادة الفهم والتأويل، وإن كان ليس مرادفًا للتأويل كما سبق؛ ولذا

19 Fahd al-Qurashî, Manhaj Hasan Hanafī: Dirāsah Taḥlīiyyah Naqdiyyah (Riyadh: al-Bayān, 1434H), 419.

20 Mu'tașim Sayyid Aḥmad, al-Hermenuitiqā fĩ al-Wāqi' al-Islāmì (Beirut: Dār al-Hādì, 2009), 58.

${ }^{21}$ Ṭahā `Abd al-Raḥmān, Fiqh al-Falsafah (al-Markaz al-Thaqāfīi al'Arabi, n.d), 38. 
Abdullah Awad, "Hermenuitics of Creed Issue," Afkār Vol. 19 Issue 2 (2017):

فإطلاق التأويلية دون التأويل هو الأنسب لما توحيه صناعة الكلمة من الزخم الذي تحمله من ابتحاهات ومناهج، فهي تضمر في داخلها جملة دونة

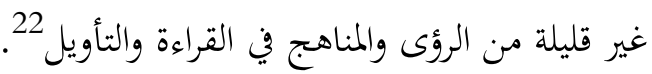

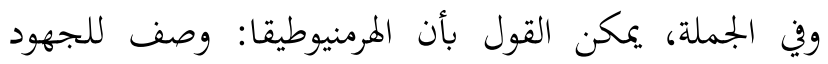

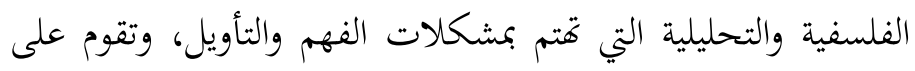
فلسفة التعمق خلف ما هو ظاهر من تعبيرات وعلامات ورموز

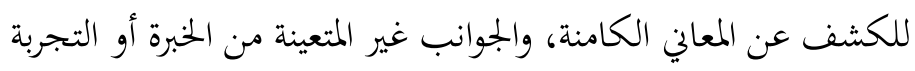

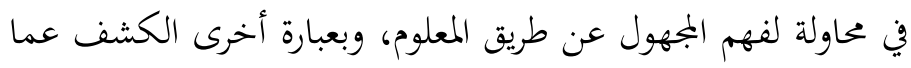

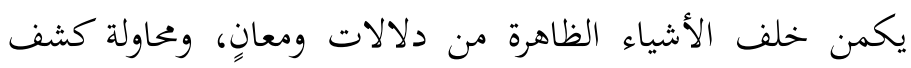
الغموض البادي في الظاهر بالتعمق خلفه، والكشف عن آفاق للمعاني لا ندركها من مجرد النظرة الخارجية. 23

\section{المبحث الأول :هرمنيوطيقا النص الثرعي 24}

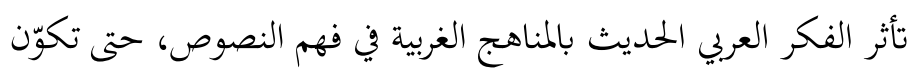

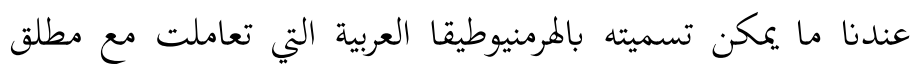

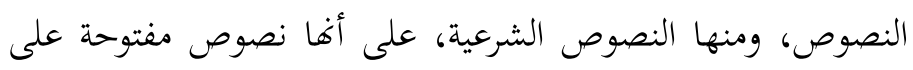

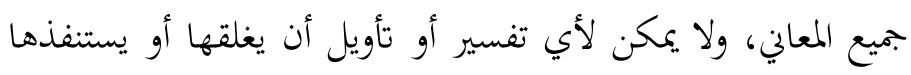

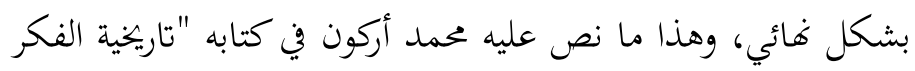

${ }^{22}$ Ismāài Niqāz, Manāhij al-Ta'wìl fī al-Fikr al-Ușūlì 146.

${ }^{23}$ Aḥmad Zāyid, al-Hermenuitiqā wa Ishkāliyyāt al-Ta'wìl, 229.

قدمت الكلام على النص الشرعي لأنه المصدر الرئيس لمسائل العقيدة. 24 
الإسلامي" "25؛ ولذا فإنه لا يتحرج عن وصف القرآن بأنه: "جموعة من الدلالات والمعاني الاحتمالية المقترحة للبشر "26.

ونجد هذا واضحًا - أيضًا - في فكر حسن حنفي الذي يقرر

بأن النص قالب بلا مضمون، يملأ هذا القالب بحسب الظروف المحيطة به 27، كما يحاول علي حرب أن يمجّد ويشجع أصحاب هذه المناهج بقوله: "ذو اللب لا يقف عند الظاهر المنطوق به، بل يقلب الغائر والمضمور والمستتر؛ أي يطلب معنى المعنى، ومعنى المعنى ليس سوى

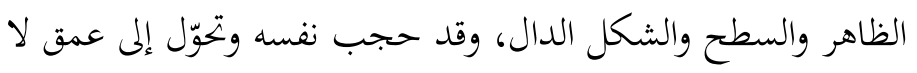
مرئي أو محتوى باطن."28.

وقد استخدموا للوصول إلى مبتغاهم من عدم الاعتداد بما يقوله النص، والخروج عن مراد قائله أو سبب نزوله، بهدف التحرر من سلطته وقراءة ما لم يقله صاحبه؛ عدة مناهج، منها: * تاريخية النص الشرعي التاريخية مصطلح نشأ في البيئة الغربية بهدف إقصاء سيطرة الموروث الديني، وتأسيس بناء معرفي جديد مزعوم، وقد أدى ظهور هذه النزعة إلى التشكيك في مصداقية الكتب المقدسة عندهم، وذلك بعرضها على

${ }^{25}$ Muhammad Arkoun, Tārìkhiyyah al-Fikr al-Islāmī, , trans. Hashìm Șạliḥ, (Beirut: al-Markaz al-Thaqāfī al-`Arabī, 1996), 145.

${ }^{26}$ Ibid., 139.

${ }^{27}$ Hasan Hanafī, al-Yasār al-Islāmī, 395:2.

28 'Alī Harb, Naqd al-Naṣ (Dār al-Bayḍā’’: al-Markaz al-Thaqāfī alArabì, 2005), 24. 
Abdullah Awad, "Hermenuitics of Creed Issue," Afkār Vol. 19 Issue 2 (2017):

طاولة البحث والنظر التاريخي لنقدها وقياس مدى صحتها، شأخا في ذلك شأن سائر الكتب.

وعند تتبع تاريخ هذه النزعة يمكن القول إن آلياتما المنهجية

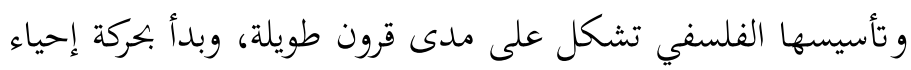

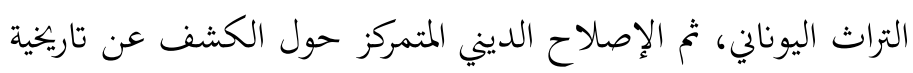

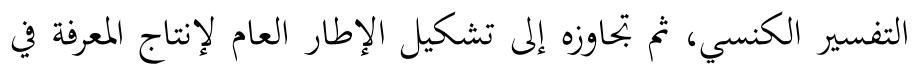

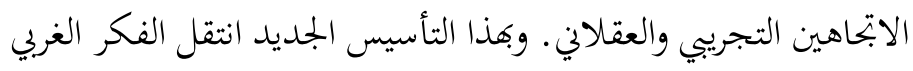

إلى طور مختلف، وإلى مرحلة جديدة من مراحل الفلسفة الحديثة التي

أصبحت هي فلسفة القرن السادس عشر والقرون التي تليه. 29

وقد ابته الفكر الغربي بذلك إلى تفسير النصوص المقدسة

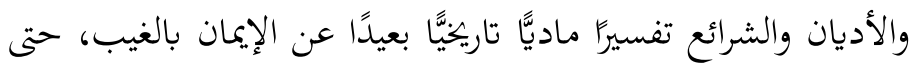

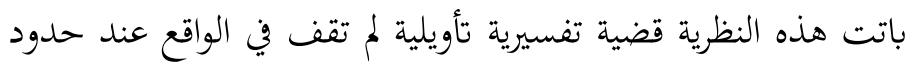

البعد التاريخي؛ بل صارت منهجًا ونظرية شاملة في الحياة، فسرها

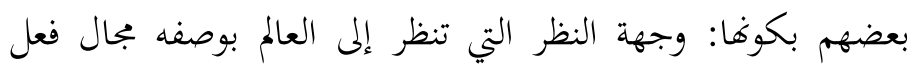

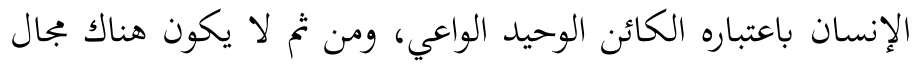

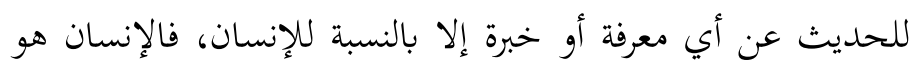
الكائن التاريخي الوحيد.

29 Andre Lalande, Mawsū'ah Laland al-Falsafiyyah, trans. Khalī Ahmad Khalil (Beirut: Awaydat li al-Nashr, 2012), 2:822.

30 -Abd al-Mun `im al-Hafnī, al-Mu jam al-Falsafī (Cairo: al-Dār alSharqiyyah, 1990), 15. 
Abdullah Awad, "Hermenuitics of Creed Issue," Afkār Vol. 19 Issue 2 (2017):

ويرى غادمير وهيدجر أن التاريخية تعني تراكمًا لخبرة الوجود في

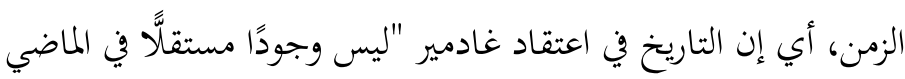

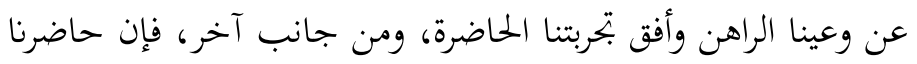

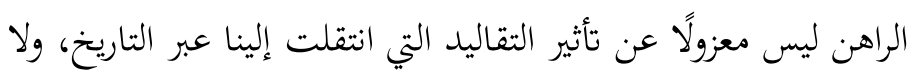

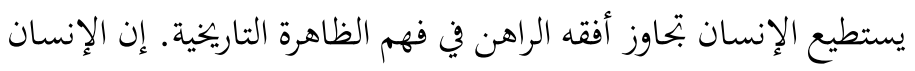

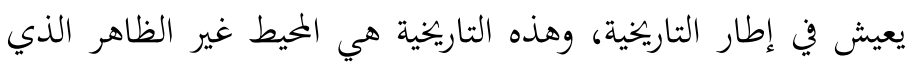

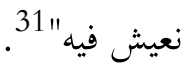
ومن هنا يمكن القول إن للتاريخية شكلين:

الأول: التاريخية الشاملة: ويراد بها إخضاع الوجود بمان بما فيه لرؤية

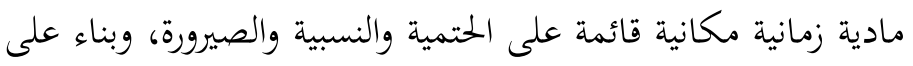
ذلك فليست الأديان والوحي إلا تجليات لتطور العقل عبر التاريخ والتجارب.

الثاني: التاريخية الجزئية: ويراد بها إخضاع النص لأثر الزمان والمكان والمخاطب مطلقًا. 32 وقد تلقف الفكر العربي هذه المناهج الغربية - كعادته - التي تتضمن في حقيقتها تعددية المعنى والدلالة ولا هُائيتهما، وعدم الاعتبار لمقاصد النص أو مراد قائله، وتغيرهما بحسب الزمان والمكان؛ ومن أوائل من نادوا بهذا المنهج من مفكري العرب محمد أركون.

${ }^{31}$ Nașr Ḥāmid Abū Zayd, Ishkāliyyāt al-Qirā 'ah, 42.

32 Sa`d Bajād al-'Utaibì, Mawqif al-Ittijāh al-'Aqlānì al-Islāmì alMu'āșir min al-Naș al-Shar ĩ (Riyadh: Markaz al-Fikr al-Mu’āșir, 1431H), 462. 
Abdullah Awad, "Hermenuitics of Creed Issue," Afkār Vol. 19 Issue 2 (2017):

ويعتبر هذا المنهج ركيزة أساسية في الفكر الأركوني؛ ذلك أنه يرى

أن هذا المنهج سيساهم في تحقيق ثورة فكرية عميقة تغيّر جذريًّ النظرة التقليدية إلى التراث، وسبب ذلك في اعتقاده "أن العقل الدوغمائي

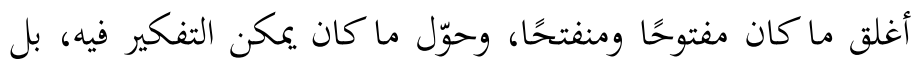

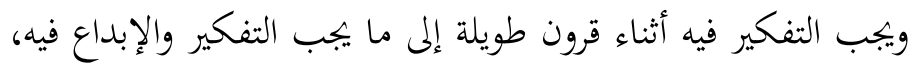

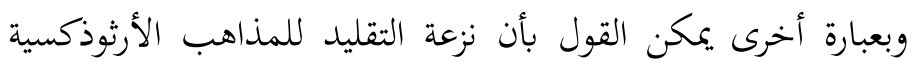

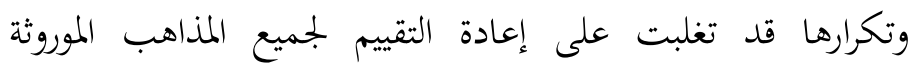
والمسلمات التعسفية التي أنبتت عليها" ومن هنا فهو يرى وجوب التركيز على هذه المناهج 34 التي من التعني شأها تحرير العقول والتحكم بنشاطها، وإزاحة كل ما يعيق انفتاحها

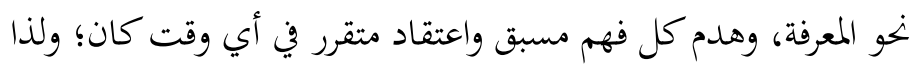

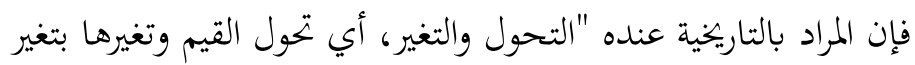

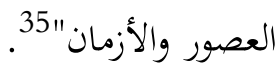

${ }^{33}$ Muhammad Arkoun, Qaḍayā fī Naqd al-`Aql al-Dīin, trans. Hashīm Șālih (Beirut: Dar al-Tali'ah, 2004), 26.

${ }^{34}$ See: Muḥammad Arkoun, Tārīkhiyyah al-Fikr al-Islāmī, 39.

وهذه المناهج في حقيقة الأمر كثيرة ومتداخلة في الفكر الأركوني، فهو يذكر أن لعلم اللسانيات بشقيه الدياكروني والسانكروني شرف السبق في التحليل، متبوعًا بعلم السيميائيات الذي يأتي في

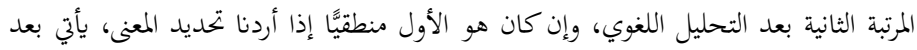
ذلك علم التاريخ والسوسيولوجيا والأثنروبولوجيا والفلسفة في المرتبة الثالثة. أما المرتبة الأخيرة فتنصب على الخطاب التيولوجي المفروض فيه الانفتاح على الخطوات التحليلية السابقة حتى لا يبقى خطابًا تبجيليَّا.

${ }^{35}$ Muhammad Arkoun, Min al-Ijtihād ila Naqd al-`Aql al-Islāmì, trans. Hashīm Șāliḥ (Beirut: Dar al-Saqī, 1991), 26. 
وفي محاولة لتكريس هذا المفهوم في الفكر الإسلامي كمنهج لنقد النصوص الدينية، يعتبر أركون التاريخية هي الوسيلة الوحيدة لقراءة الوحي؛ ولذا فهو يرى أن "التاريخية ليست مجرد لعبة ابتكرها الغربيون

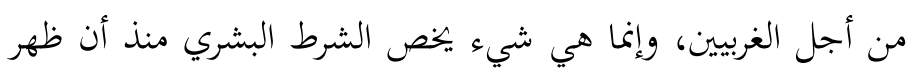

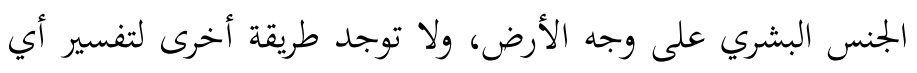
نوع من أنواع ما ندعوه الوحي، أو أي مستوى من مستوياته خارج تاريخية انبثاقه وتطوره أو نموه عبر التاريخ، ثم المتغيرات التي تطرأ عليه تحت ضغط التاريخ". 36

وين موضع آخر يصرح بقوله: "أريد لقراءتي هذه أن تطرح مشكلة لم تطرح عمليَّا قط بهذا الشكل من قِبَل الفكر الإسلامي، ألا وهي: تاريخية القرآن، وتاريخية ارتباطه بلحظة زمنية وتاريخية معينة"37 ويهدف أركون من ذلك إلى تأكيد إدخال التاريخية38 إلى ساحة الفكر العربي الإسلامي؛ بكيث يكون للأحداث و والممارسات

36 Muḥammad Arkoun, al-Fikr al-Islāmì Qirā'ah 'Ilmiyyah, trans. Hashīm Șālih (Beirut: Dar al-Saqi, 1991), 116.

${ }^{37}$ Ibid., 212.

38 See: Ibid., 23; Aḥmad al-Ṭāān, al-'Ilmāniyyūn wa al-Qur'ān alKarìm, (Riyadh: Dār Ibn Hazm, 2007), 300.

يجدر التنبيه هنا إلى أن محمد أركون يفرق بين: التاريخية والتاريخانية؛ فالتاريخية (Historicite) عنده لما معنى إيجابي يتوجه إلى دراسة التغير والتطور الذي يصيب البنى والمؤسسات والمفاهيم من خلال مرور الأزمان وتعاقب السنوات، وهي التي يسميها: التاريخية الراديكالية، وأما التاريخانية أو التاريخوية الوضعية (Historicisme) فتحمل معنى سلبيَّا، وهو التعبير عن النزعة المتطرفة في دراسة التاريخ، والارتباط بالفلسفة الوضعية والنظرة الفللوجية التي سادت في القرن التاسع عشر لئي 
Abdullah Awad, "Hermenuitics of Creed Issue," Afkār Vol. 19 Issue 2 (2017):

والخطابات أصلها الواقعي، وحيثياتا الزمانية والمكانية، وشروطها المادية والدنيوية، فتخضع البنى والمؤسسات والمفاهيم للتطور والتغير، أي قابليتها للتحويل والتصرف وإعادة التوظيف. 39 ومن هنا فإن ما يعتقده المسلمون في القرآن باعتباره أحكامًا أزلية ثابتة، جاءت القراءة التاريخية لرفعه وبتحاوزه، وأن ما فيه ليس سوى شواهد تاريخية تدل على طور من أطوار الوعي الإنساني تم بتحاوزه الآن؛ ولذا يقول نصر حامد أبو زيد: "إذاكانت النصوص الدينية نصوصًا بشرية بحكم انتمائها للغة والثقافة في فترة تاريخية محددة هي فترة تشكلها وإنتاجها، فهي بالضرورة نصوص تاريخية، بمعنى أن دلالتها لا تنفك عن النظام اللغوي الثقافي الذي تعد جزءًا منه، ومن هذه الزاوية تمثل اللغة ومحيطها الثقافي مرجع التفسير والتأويل" "40. وبعبارة أخرى، فإن القول بتاريخية النص يعني أن النص حادث في وقت معيّن، وله تعلق ببيئة معينة وأحداث مخصوصة، وهذا يعني أنه يعالج ظروف تلك الحقبة الزمنية التي نزل فيها دون غيرها مما يكون بعدها، وهذا ما دفع أبو زيد إلى القول بأن "النص القرآي يعكس واقعًا

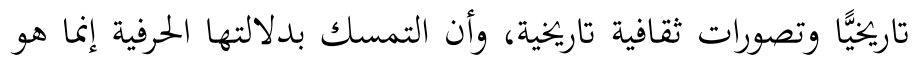

وأوائل هذا القرن، وتعنى بدراسة التاريخ وكأنه محكوم بفكرة التقدم المستمر في ابتحاه محدود وثابت ومعروف سلفًا.

39`Ali Harb, Naqd al-Naș, 66.

${ }^{40}$ Nașr Ḥāmid Abū Zayd, Naqd al-Khițāb al-Dinni (al-Markaz al-Thaqafi al-'Arabi, 2007), 209. 
تثبيت لصورة واقع بتحاوزه التاريخ والثقافة" 41، ويؤكد في موضع آخر

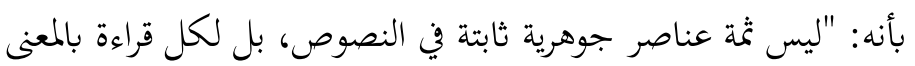

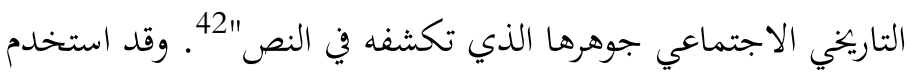
أبو زيد في سبيل ترسيخ هذه النظرية آليتين

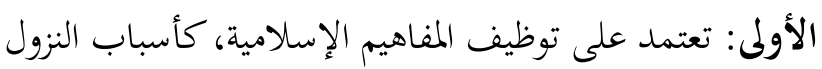

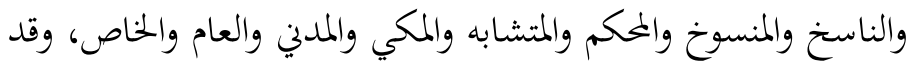

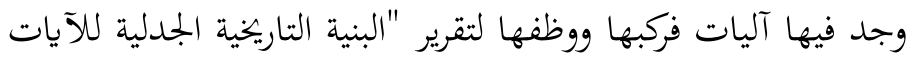

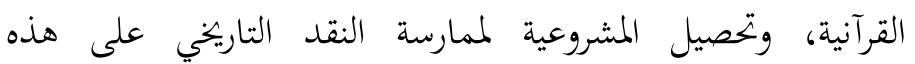
الآيات" الترآنة.

والثانية: توظيف المفاهيم اللسانية؛ إذ يحاول الاعتماد على لئ اعتباطية اللغة بكوها ليست دليلاً على الوجود الفعلي الحقيقي، وإنما

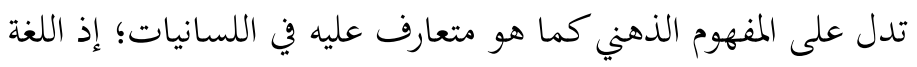

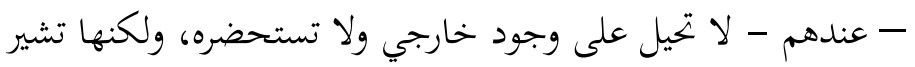

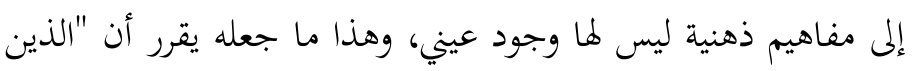
يستدلون على وجود ظواهر السحر والحسد بوجود الألفاظ الدالة عليها في النص الديني يقعون في خطأ التسوية بين الدالّ والمدلول"45ون.

${ }^{41}$ Ibid., 211.

${ }^{42}$ Ibid., 118.

${ }^{43}$ Hamìd Samīr, Namūzaj al-Hadāthah wa mā Ba'dahā fì al-Fikr alArabi al-Hadith (Saudi Arabia: Markaz Takwīn, 2017), 211.

${ }^{44}$ Nașr Hāamid, Naqd al-Khițāb al-Dīnì, 185.

${ }^{45}$ Ibid., 219. 
وأما أركون، فيرى أن الوحي أصلًا "ليس كلامًا معياريَّ نازلًا من

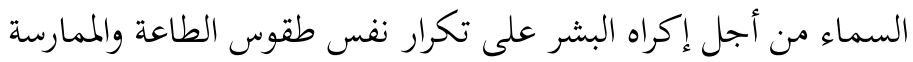

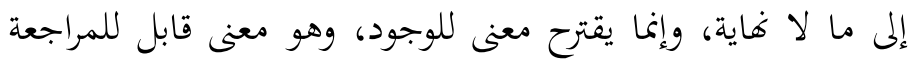
والنقض" 46، ولا يستقيم معنى تاريخية الوحي - عنده - إلا بالتمييز

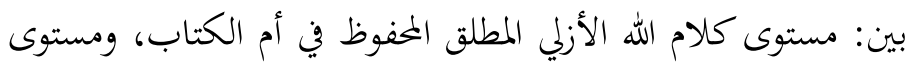

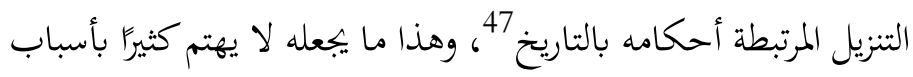

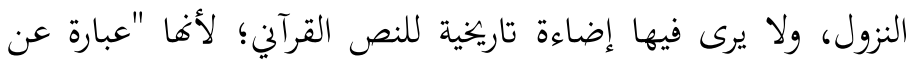

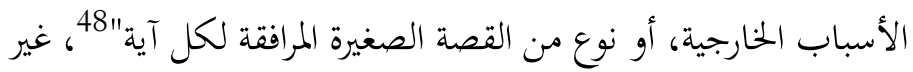
أنه اهتم كثيرًا بالناسخ والمنسوخ في النص، واستخدمه دليلاً على على تاريخية

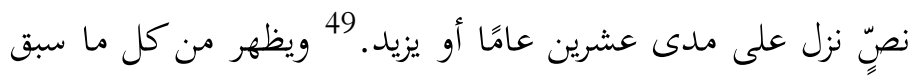

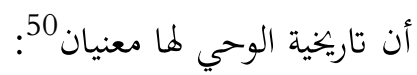

المعنى الأول: أن الوحي كان نتيجة للظروف التاريخية، وإفرازًا

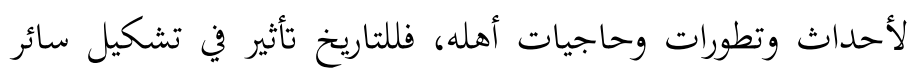
المعاني والأحكام، وتتفق هنا صفة التاريخية مع صفة الثقافية، باعتبار أن كلَّا منهما مثّل إطارًا لصياغة الوحي.

${ }^{46}$ Muhammad Arkoun, al-Qur'ān min al-Tafsìr al-Mawrūth ila Tahlīl al-Khitāa al-Dinin, trans. Hashīm Sālị̣ (Beirut: Dar al-Tali'ah, 2005), 32.

${ }^{47}$ Ibid., 22.

${ }^{48}$ Ibid., 115.

49 'Abd Allāh Balqīiz, Naqd al-Turāth (Beirut: Markaz Dirāsah alWihndah al-`Arabiyyah, 2016), 396.

50 'Abd al-Majìd al-Najjār, al-Qirā'ah al-Jadìdah li al-Naș al-Dinin (Damascus: Markaz al-Fikriyyah, 2006), 138; Nūr al-Dīn al-Khādimí, al-Qirā'ah al-Ta'wìliyyah li al-Qur'ān al-Karim (Damascus: Dār alGhuthani, 2014), 178. 
المعنى الثاني: أن الوحي كان خطابًا موجهًا إلى فترة تاريخية محددة، وإلى من كانوا موجودين زمن نزوله، ومن استمروا بعد ذلك على الوضع ذاته. أما غيرهم فيحق لهم أو يجب عليهم عدم الامتثال للوحي

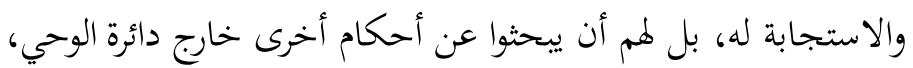
أو داخله، لكن بأفهام وتفسيرات تساير الظروف الجديدة والأوضاع المستجدة حتى ولو كان اللفظ لا يحتملها.

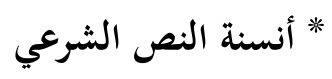

النزعة الإنسانية (humanism) - كما جاء في موسوعة لالاند الفلسفية - هي: "حركة فكرية يمثلها إنسانيو النهضة، وتتميز بمجهود لرفع كرامة الفكر البشري، وجعله جديرًا ذا قيمة؛ وذلك بوصل الثقافة الحديثة بالثقافة القديمة" 51 وأوضح سماتها السعي إلى الإعلاء من سلطان العقل، ومقاومة السلطة والجمود، وسبيل أنصارها تحطيم قيود العصر القديك 52.

وقد أطلقت هذه النزعة على المفكرين الذين اهتموا بالإنسان في عصر النهضة، وهم الذين "آمنوا بأن الإنسان معيار كل شيء، وأن كل إنسان معيار ذاته"53، وهي إحدى ردود الفعل ضد سلطة الكنيسة الجائرة؛ ولذا فقد تعالت أصوات الداعين إليها في عصر التنوير بسبب

${ }^{51}$ Lalande, Mawsū`ah Lalande al-Falsafiyyah, 2:566.

${ }^{52}$ Murād Wahbah, al-Mu'jam al-Falsafī (Cairo: Dār Qaba li al-Ṭiba`ah, 1998), 105.

53 Crane Brenton, Tashkìl al-`Aql al-Hadith, trans. Shawqī Allam (Kuwait: Alam al-Ma`rifah, n.d), 40. 
الاكتشافات العلمية، وبروز جيل واسع من المثقفين بتمعهم الرغبة في التخلص من التدخل الكنسي في شؤون الحياة الفردية والاجتماعية، واتفق أغلب الإنسانيين على استبعاد التفسيرات التي تقدمها أديان

$$
\text { الوحي واعتبارها ضربًا من الأوهام. }
$$

ويمكن القول إن نظرية الأنسنة أو الذاتية قد شكلت قاعدة

الحداثة في مجالها الفلسفي، وهي أكثر خصائص الحداثة وضوحًا وتداخلاً مع جوهرها وموضوعها، ولذا يقول فيتو: "الحداثة هي أولوية الذات، وانتصار الذات، ورؤية ذاتية العالم" أها: "ذلك التأويل الفلسفي للإنسان الذي يفسر ويقيم كلية الوجود انطلاقًا من الإنسان وفي ابتحاه الإنسان"

وقد أخذ الحداثيون العرب هذا المذهب من الفلسفة الغربية

واجتهدوا في محاولة تطبيقه على النصوص الشرعية، وأرادوا بذلك رفع القدسية عنها، وتحويلها من مكانتها ذات المصدر الإلهي إلى نصوص ذات طابع بشري، فهدفهم الذي صرحوا به هو: "نزع الميثية عن النص الديني بمحاولة أنسنته بعلمنة القراءة"57، ويدل على هذا ما يلي:

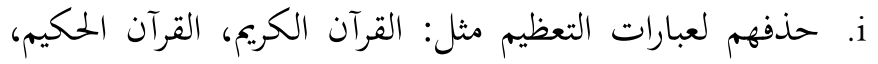
قال الله تعالى، الآية الكريمة، ونحوها من العبارات.

${ }^{54}$ Aḥmad al-Ṭa ān, al-'Ilmāniyyūn wa al-Qur'ān al-Karìm, 16.

${ }^{55}$ Muhammad al-Shaykh and Yāsir al-Ṭā'i, Muqārabāt fī al-Hadāthah wa mā ba'd al-Hadāthah (Beirut: Dār al-Tali'ah, 1996), 12.

${ }^{56}$ Muhammad Sālim al-Nu`aymī, al-Qirā'ah al-Hadāthiyyah li al-Naș al-Qur'āni (Cairo: Mișr al-'Arabiyyah li al-Nashr, 2016), 26.

57 'Abd al-Majīid al-Sharafī et. al., Fì Qirā'ah al-Naș al-Dīnì (Tunisia: al-Dār al-Tūnis li al-Nashr, 1990), 95. 
Abdullah Awad, "Hermenuitics of Creed Issue," Afkār Vol. 19 Issue 2 (2017):

ii

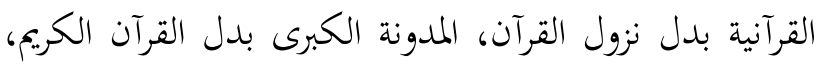

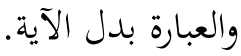

iii التسوية في الاستدلال والاستشهاد بين الكلام الإلهي والكلام الإنساني.

iv

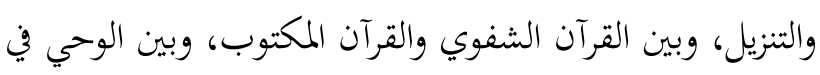
اللوح المففوظ والوحي في اللسان العربي.

v. المماثلة بين القرآن والنبي عيسى (عليه السلام)؛ فالقرآن كلام الله، وعيسى كلمة الله.

والحقيقة أن الأنسنة العربية لا تختلف كثيرًا عن نظيرتها الغربية من

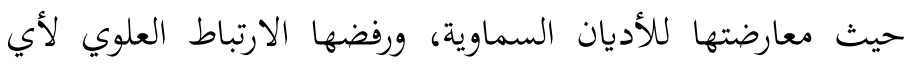

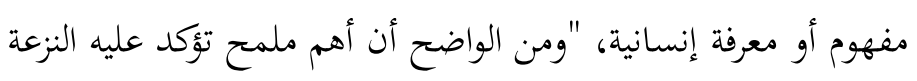

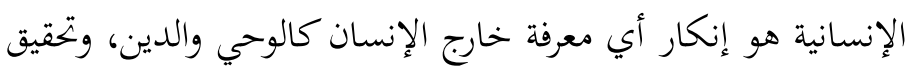

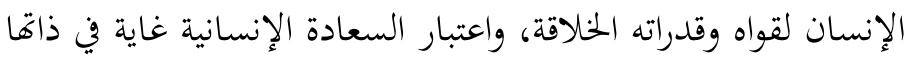
لا تتطلب أي تبريرات خارج الإنسان"

وهذا لا يعني أن القائلين بها على درجة واحدة، بل بل هم في حقيقة الأمر متفاوتون، فمنهم من يجعل الدين من صنع الإنسان كمراد وهبة

${ }^{58}$ Ṭahā `Abd al-Rahmmān, Rūh al-Hadāthah (Dār al-Bayḍā’: al-Markaz al-Thaqafī al-`Arabi, 2006), 178-179.

59 `Āṭif Aḥmad, al-Tawajjuh al-Insānì Tahlìil Mafhūmì, 39. 
Abdullah Awad, "Hermenuitics of Creed Issue," Afkār Vol. 19 Issue 2 (2017): 143-204

الذي يقول: "إن الإنسان هو الذي يصنع الدين وليس العكس، فالدين

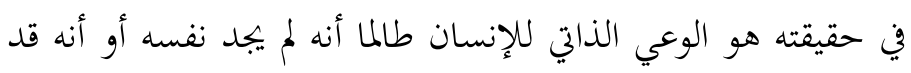

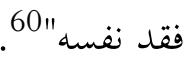

ومنهم من جعل أولويته في تطبيق ذلك على الكتب السماوية

والوحي الإلهي، بل والنص القرآني على وجه الخصوص، ومن أشهرهم

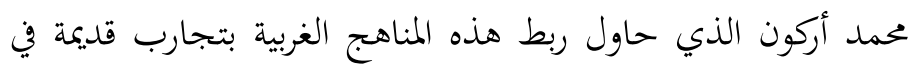

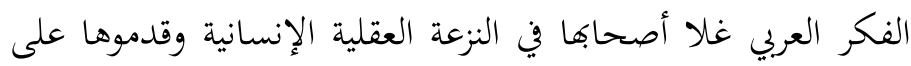

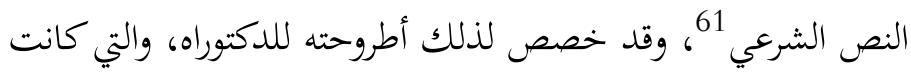
بعنوان: "نزعة الأنسنة في الفكر العربي جيل مسكويه والتوحيدي". 62 ولذا فهو يقرر في كتابه (القرآن من التفسير الموروث إلى تحليل الخطاب الديني) أن "الوحي نفسه لا ينفصل عن الوظيفة النبوية،

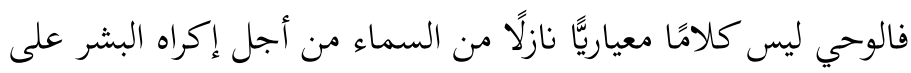

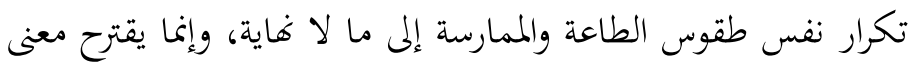

${ }^{60}$ Murād Wahbah, Malāk al-Haqiquah al-Muṭlaqah (Cairo: Dār Qubā, 1999), 329.

${ }^{61}$ See: Arkoun, al-Fikr al-Islāmī, 19 and 79.

وقد كان هذا في القرن الرابع الهجري الذي شهد بحارب صوفية وباطنية وفلسفية كتلك التي تذكر عن أبي حيان التوحيدي وابن مسكويه، وهناك شخصيات أخرى شاركت - كما يرى - في تري هذه التجربة؛ كالجاحظ، والقاضي عبد الجبار، وابن سينا، وإخوان الصفا وغيرهم، والواقع أن

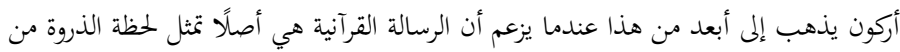

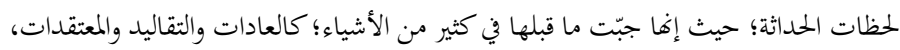
فالقرآن كما يقول يقدم نفسه ويمارس دوره على هيئة حداثة.

${ }^{62}$ Aḥmad al-Lahayib, Mafhūm al-Ansanah: `Arḍ wa Naqd, Baḥth Damn Majallah al-Dirāsāt al-Islāmiyyah, Jāmi`ah al-Malik `Abd al-Azīz vol. 27, 286. 
Abdullah Awad, "Hermenuitics of Creed Issue," Afkār Vol. 19 Issue 2 (2017):

الوجود، وهو معنى قابل للمراجعة والنقض، انظر الآيات الناسخة والمنسوخة في القرآن، كما أنه قابل للتأويل داخل إطار الميثاق أو العهد المعقود بكل حرية بين الإنسان والله"، ويحاول قبل هذا أن يمدح النبي (صلى الله عليه وسلم) ببعض العبارات كقوله: "النبي شخص ملهم، راءٍ أو رؤيوي، حكيم، صاحب خيال وثّاب، قائد، روح جبارة قادرة على سبر أغوار المجهول وانتهاك الحدود المضروبة على المعرفة وبتحوزها أو تخطيها بفضل الإلهام المستمر الذي يزوده الله به" ويريد بما سبق جعل الوحي من كلام النبي (صلى الله عليه وسلم)، ويهيله إلى ذكائه وفطنته وحكمته، وأنه إلهام من الله له إلا أنه هو الذي تكلم به. ومن بين تلك المحاولات مشروع نصر حامد أبو زيد الذي يهدف إلى: - إن

1. نقد التراث وتحليله مع تركيز الاهتمام على النص القرآني بشكل خاص بوصفه محور الثقافة الإسلامية.

2. تقديم تأويل علمي أو فهم موضوعي يتحرر من النظرة

التقديسية للنص، ولذذا يندرج كتابه (مفهوم النص) ضمن الأعمال المخصصة لنقد الفكر الديني عمومًا، وللخطاب

$$
\text { القرآني خصوصًا. }
$$

وقد تناول في الكتاب السابق النص القرآني بوصفه منتجًا ثقافيَّا - ينتمي إلى الثقافة العربية التي أنتجها الواقع التاريخي والاجتماعي

${ }^{63}$ Arkoun, al-Qur'ān min al-Tafsìr al-Mawrūth, 85. 
Abdullah Awad, "Hermenuitics of Creed Issue," Afkār Vol. 19 Issue 2 (2017):

للعرب في عهد النبوة - وليس وحيًا متعاليًا، وهو بهذا يقترب في طريقة تعامله مع القرآن من أركون، 64 الذي يعتبر الخطاب القرآني شأنه شأن أي خطاب ديني هو نتاج معري يخضع للشروط النقدية التي تخضع لها النتاجات المعرفية الأخرى؛ أي خطابات البشر. ومقتضى التشابه المزعوم السابق هو فصل النص القرآي عن مصدره الإلهي، وتحويله إلى بنية لغوية ونصية ذهنية بشرية، ونفي مقاصده العقدية والخلقية والتربوية، والاقتصار على الوظيفة اللغوية فقط؛ ولذا ففهمه لا يكون إلا من خلال العقل الإنساني الذي يقيّده بالواقع والثقافة التي نشأ فيها دون أي اعتبار آخر، وبذلك يكون نصَّا كسائر النصوص البشرية قابلاً للنقد والتصحيح، ولا تكون أحكامه عامة شاملة، ولا تتجاوز حدود الزمان والمكان.

\section{المبحث الثاني :هرمنيوطيقا قضايا الألوهية}

ظهر مما سبق أن النظريات التأويلية السابقة تساوي بين النصوص سواء كانت إلهية أو بشرية، ولا تفرق بين نصوص الأحكام أو نصوص العقائد؛ ولذا فإن فهم النصوص جميعها بما فيها نصوص العقائد متغيّر اعتمادًا على اللغة الجماعية التي يتكلم بها مستقبلو النص؛ إذهي هي

${ }^{64}$ Hamid Samir, Namūzaj al-Hadāthah, 86.

${ }^{65}$ See: Nașr Ḥāmid, Naqd al-Khițāb al-Dìnī, 206.

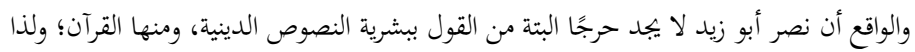

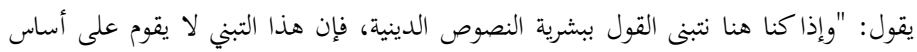

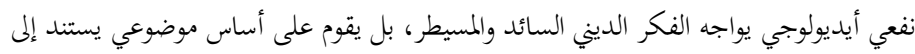
حقائق التاريخ وإلى حقائق النصوص ذاتها". 
متحركة ضرورة بناء على الفعالية الاجتماعية كما يؤكده علم اللسانيات الحديث، إضافة إلى العوامل السيكولوجية والثقافية والسياسية، وهذا ما يجعل العقائد التي تؤسسها تلك النصوص متغيرة ضرورة، وهذا التغير هو الذي تدعمه النظريات الحديثة للتأويل بغالب أطيافها. 66 ولذا يعمد الحداثيون إلى إدراج موضوع العقائد والغيب في مباحث العلوم الإنسانية؛ كعلم النفس التاريخي، وعلم الاجتماع الديني، فيصبح الإيمان بالغيب ضربًا من الأمل في النجاة والعدالة المفقودة التي كرستها معطيات تاريخية معينة، ويجعلون الإيمان بالغيب حلمًا لا صلة له بالحقيقة، وتصورات ليس بالضرورة أن يكون لها وجود بالفعل. 67 ويعلق محمد أركون تأخر الدراسات الإسلامية على اعتقاد ثبات العقائد، ويجعل التسليم لها ورفض تاريخيتها هما العقبة في وجه تقدم الدراسات الإسلامية والفكر العربي؛ إذ هي كما يقرر "مرتبطة بلحظة تاريخية ما، وبصراعات أيديولوجية معينة، وليست نازلة من السماء، إفا من صنع البشر "68.

ويصف نصر حامد أبو زيد تعامل اليسار الإسلامي مع العقائد بكوها تصورات ذهنية تمثل موجهات للسلوك أكثر من كوفا عقائد

${ }^{66}$ Khālid al-Sayf, Zāhirah al-Ta'wìl al-Hadìthah fï al-Fikr al- 'Arabī alMu āșir (Jeddah: Markaz al-Ta'sīl li al-Dirāsat, 2015), 302.

${ }^{67}$ Muhammad Arkoun, al-Fikr al-Ușūlì wa Istihălah al-Ta'șill, trans. Hashìm Șālị̣ (Beirut: Dar al-Saqi, 2002), 56.

${ }^{68}$ Muhammad Arkoun, Min Fayșal al-Tafriqah ila Fasl al-Maqāl: Ayna Huwa al-Fikr al-Islāmī, trans. Hashìm Șāliḥ (Beirut: Dar al-Saqi, 1995), 71. 
Abdullah Awad, "Hermenuitics of Creed Issue," Afkār Vol. 19 Issue 2 (2017):

دالة على وجود مفارق 69، وأما حسن حنفي فيجزم بأنه لا يمكن التسليم

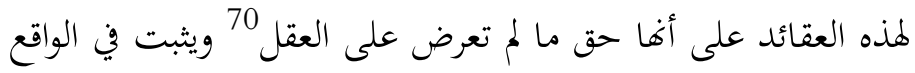

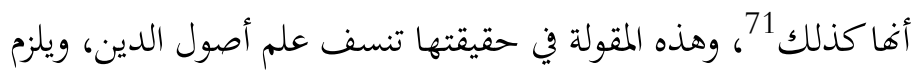
منها ألا يكون للغيب وجود عندهم.

ويحاول أصحاب الموقف الأيديولوجي أسطرة العقائد ودراستها

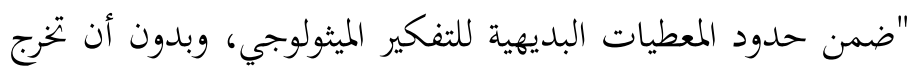

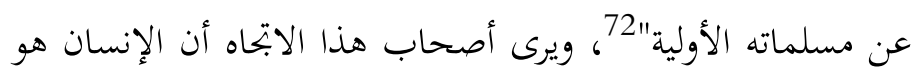

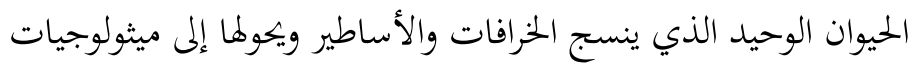

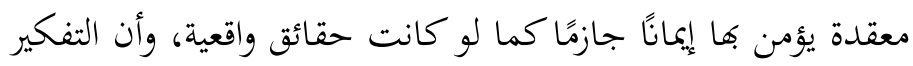

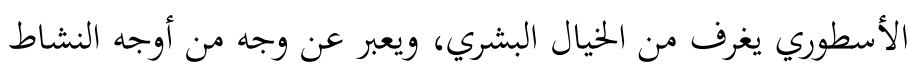

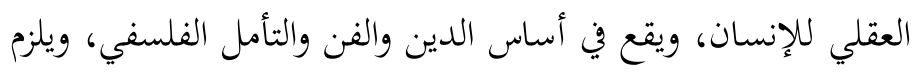

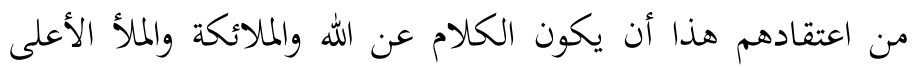
والجن وإبليس وغيرها من الغيبيات لا يشير إلى مسميات حقيقية

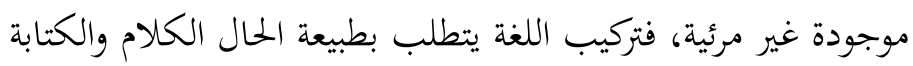

${ }^{69}$ Nașr Ḥāmid, Naqd al-Khiṭāb al-Dīnī, 173.

${ }^{70}$ Hasan Hanafi, al-Dīn wa al-Thawrah fi Miṣr, 2:52. Fahd al-Qurashi, Manhaj Hasan Hanafï, 194.

يرى حسن حنفي أن العقل مصدر مستقل للمعرفة، وليس في حاجة إلى عون أحد لا إله، ولا وحي، ولا نبي، ويسعى من خلال مشروعه "التراث والتجديد" إلى تحرير العقل من سلطة الوحي كما فعل فلاسفة التنوير؛ ولذا يقول: "لن نصل إلى عصر التنوير إلا إذا جعلنا للعقل سلطانه دون سلطة الكتاب أو سلطة التقاليد الموروثة".

${ }^{71}$ Hasan Hanafī, Min al-`Aqìidah ilā al-Thawrah, 1:30.

72 Șādiq Jalāl al-`Aẓm, Naqd al-Fikr al-Dīnì (Beirut: Dār al-Talìah, 2003), 57. 
Abdullah Awad, "Hermenuitics of Creed Issue," Afkār Vol. 19 Issue 2 (2017): 143-204

بطريقة معينة توحي في الظاهر وكأن الشخصيات موجودة بالفعل، ولكن يجب ألا يخدعنا الوهم اللغوي. 73

ومن هنا فهُم يلتزمون التفسير المادي لنشأة الدين، هذا التفسير التهير الذي ورثوه عن بعض فلاسفة التنوير مثل فيورباخ، فليس الدين تنزيلاً

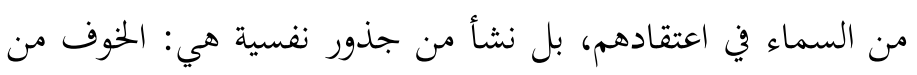
القوى الخفية، وحاجة الإنسان إلى التوصل إلى أسباب الظواهر.

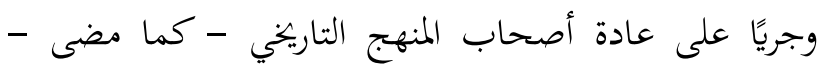

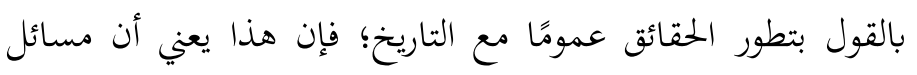

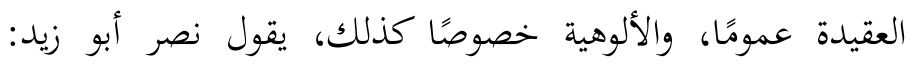

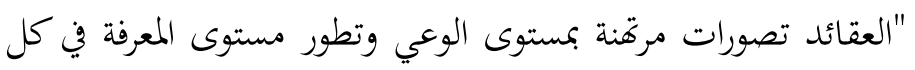
عصر "74. وما كانت الرؤية التاريخية قد حكمت على على مسائل العقيدة

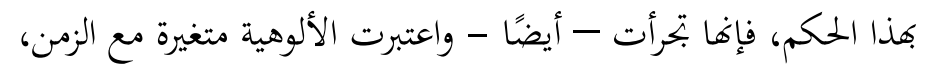

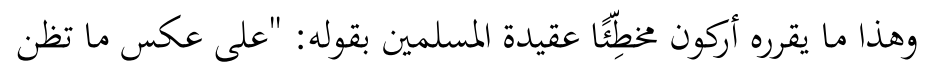
المسلمة التقليدية التي تفترض وجود إله حي ومتعالٍ وثابت لإن لا يتغير،

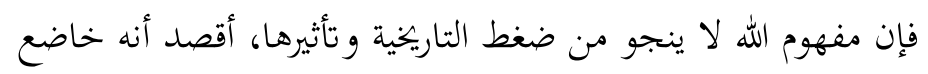
للتحول والتغير بتغير العصور والأزمان". 75

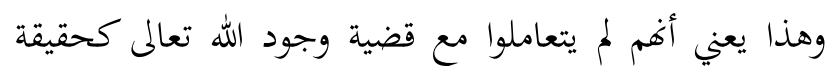
موضوعية موجودة بالفعل، بل سعوا إلى تأويل هذا الوجود تأويلاً

${ }^{73}$ Ibid., 58-59.

${ }^{74}$ Nașr Hāmid Abū Zayd, al-Naș wa al-Sulțah wa al-Haqiquah Irādah alMa 'rifiyyah wa Irādah al-Himanah (Dār al-Bayḍā': al-Markaz alThaqafï al-'Arabì, 2006), 134.

${ }^{75}$ Arkoun, al-Fikr al-Islāmì, 102. 
Abdullah Awad, "Hermenuitics of Creed Issue," Afkār Vol. 19 Issue 2 (2017):

يتناسب مع مناهج تأويلاقهم الحديثة، فزعموا أنه عبارة عن تصور خضع لتأثيرات متعددة بداية من ناحية اللغة كما يقرره علم اللسانيات

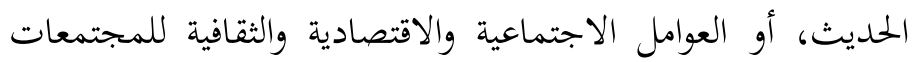

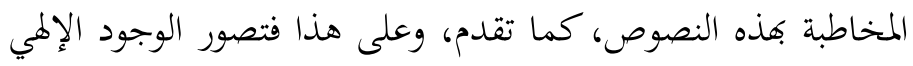

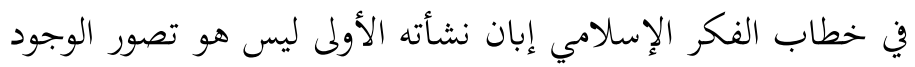
الإلهي في العصور المتأخرة. 76

وهذا الأمر هو الذي جعل أركون يتجرأ في زعمه تحديد مراحل

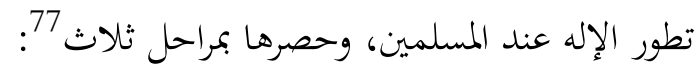

الأولى: مرحلة القرآن، وكان المطلوب فيها إدراك الألوهية، وتصور الإله بمثابة فاعل أو نموذج حاضر باستمرار في الحياة اليومية للنبي والمؤمنين.

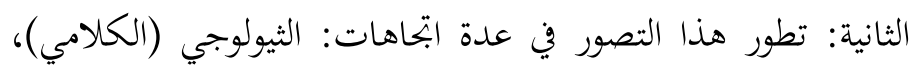
والصوفي، والفلسفي، والشعبي، ثم العقلاني اليوم.

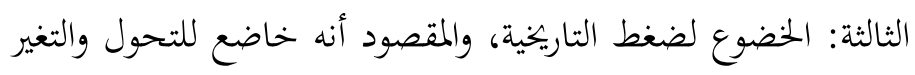
بتغير العصور والأزمان.

فأركون هنا يماول توظيف اللسانيات الحميثة والتحليلات

السيميائية والاجتماعية والعلوم الإنثربولوجية في تباوز مفهوم (الله)

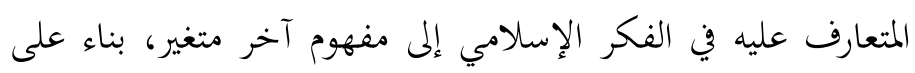

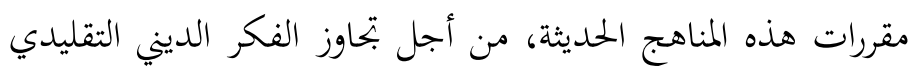

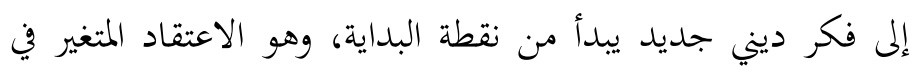

${ }^{76}$ Khālid al-Sayf, Z̄āhirah al-Ta'wìl, 305.

${ }^{77}$ Arkoun, al-Fikr al-Islāmì, 101-102. 
Abdullah Awad, "Hermenuitics of Creed Issue," Afkār Vol. 19 Issue 2 (2017):

مفهوم (الله) إلى المسائل التي تندرج تحت هذا الأصل، والتي تترتب على الاعتقاد بذلك المفهوم.

ويطرح الفكر الحداثي بقوة فكرة محورية الإنسان في الكون متخلّيّا

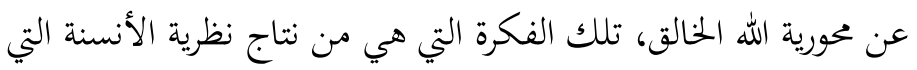
عبر عنها هيدجر - كما سبق - بقوله: "ذلك التأويل الفلسفي للإنسان الذي يفسر ويقيم كلية الوجود انطلاقًا من الإنسان، وفي ابتحاه

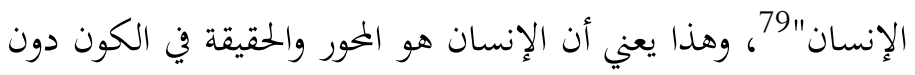

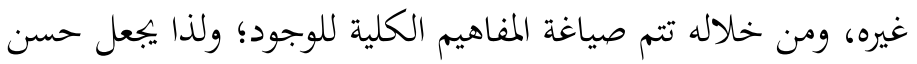
حنفي هذا التصور بديلاً عن عقيدة الألوهية في الفكر الإسلامي بقوله:

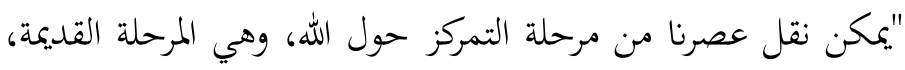
إلى مرحلة التمركز حول الإنسان، وهي المرحلة الحالية" 80. وتظهر خطورة هذه التأويلات عندما نعرف أن الغاية منها

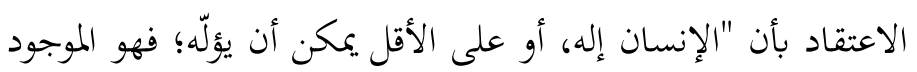

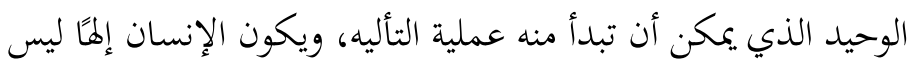

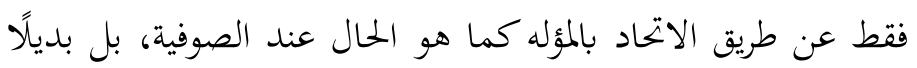

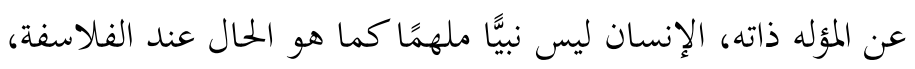

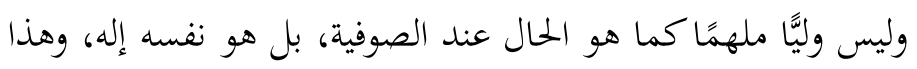

\footnotetext{
${ }^{78}$ Khālid al-Sayf, Zāhirah al-Ta'will, 307.

${ }^{79} \mathrm{Al}-\mathrm{Nu}$ aymī, al-Qirā'ah al-Hadāthiyyah, 26.

${ }^{80}$ Hasan Ḥanafí, al-Turäth wa al-Tajdìd, 122.
} 
Abdullah Awad, "Hermenuitics of Creed Issue," Afkār Vol. 19 Issue 2 (2017):

يجعل الإنسان في أعلى مستوى من الشرف بالنسبة للموجودات

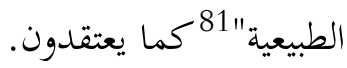

وهذا الأمر هو ما قرره حسن حنفي في نظريته (الإنسان الكامل)

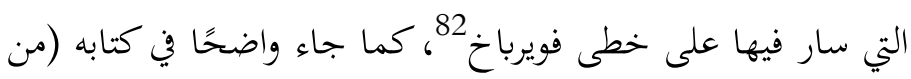
العقيدة إلى الثورة)83؛ ذلك أن فويرباخ قد سعى إلى إعادة الدين إلى إنى

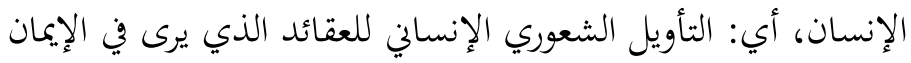

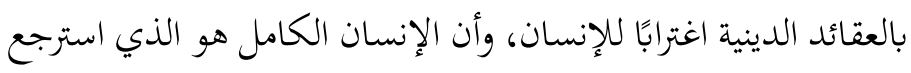

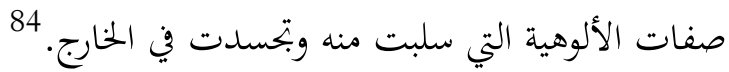
وبسبب هذا الغلو وتلك النظرية سلبوا الذات الإلهية صفاتما التي

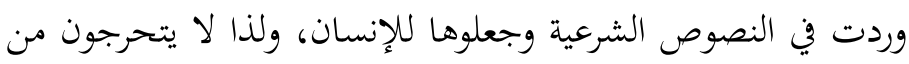
القول بأن ما ذكره علماء أصول الدين عن الله وذاته وصفاته وأفعاله

${ }^{81}$ Ḥasan Ḥanafí, Min al-`Aqìdah ilà al-Thawrah, 2:163.

82 See: Zakariyyā Ibrāhīm, Mushkilāt Falsafiyyah Mu'āṣarah (Musykilah al-Insān) (Cairo: Maktabah Mișr, n.d), 182.

يرى فويرباخ أن الإنسان هو الذي خلق الله على صورته ومثاله، فهو إنما يتعبد لنفسه حينما

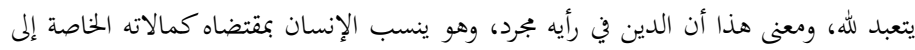

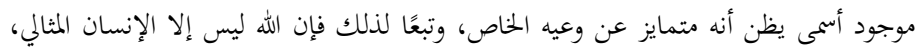

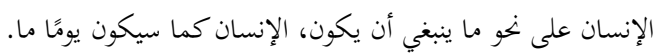

${ }^{83} \mathrm{Ibid}$.

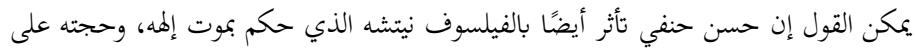

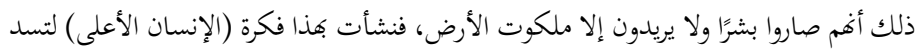

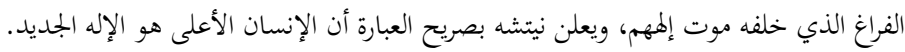
${ }^{84}$ Ibid., 272. 
Abdullah Awad, "Hermenuitics of Creed Issue," Afkār Vol. 19 Issue 2 (2017):

إنما هو في الحقيقة وصف للإنسان الكامل، فكل ما وصفوه على أنه الله فهو الإنسان مكبر إلى أقصى حدوده! 85

وبذلك ينفي حسن حنفي أن تكون هذه الصفات لله، ويزعم

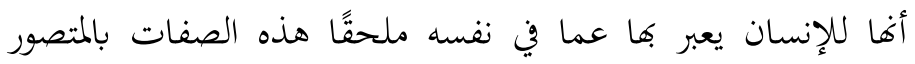

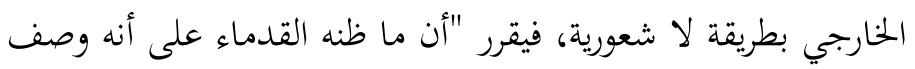
موضوعي لحقيقة واقعة في الخارج هو في الحقيقة وصف ذاتي لشعور

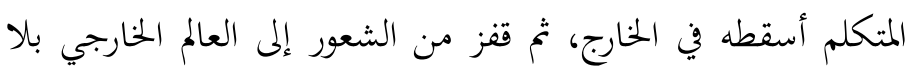

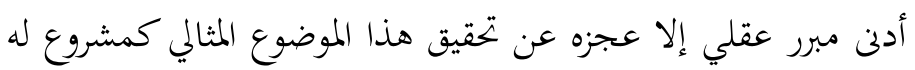

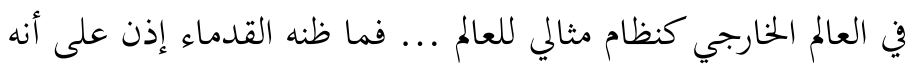
وصف لله بالفعل هو في الحقيقة وصف للإنسان، ولما كان الله هو

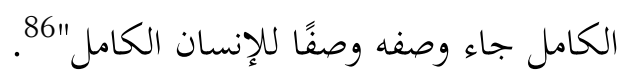

ويضرب أمثلة للصفات السابقة بصفات البقاء، والقدم،

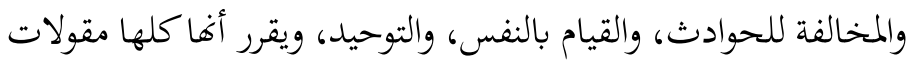

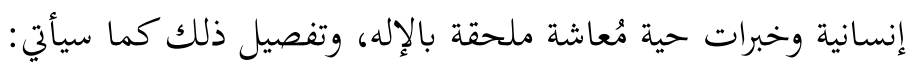

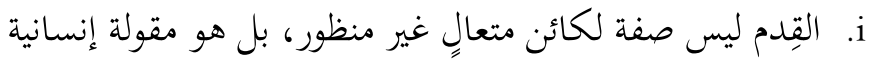

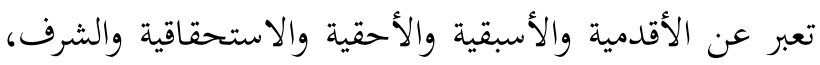
وهو العمق التاريخي للبشرية ووعي الإنسان بالزمان باعتباره وعيًا تاريخيَّان

${ }^{85}$ Hasan Hanafï, al-Turāth wa al-Tajdìd, 127.

${ }^{86}$ Heasan Ḧanafî, Min al-`Aqìdah ilà al-Thawrah, 2:556.

${ }^{87}$ Ibid., 2:130. 
Abdullah Awad, "Hermenuitics of Creed Issue," Afkār Vol. 19 Issue 2 (2017):

ii وأما البقاء، فهو تعبير عن رغبة الإنسان في الخلود والاستمرار في المستقبل، وعن خبرة معاشة في حياة الإنسان، وهي بقاء الفكر بعد موت صاحبه، وبقاء الذكريات في وعي الآخرين، وبقاء الأبطال في خيال وشعور الناس، وبقاء الأعمال الصالحة والحير

$$
\text { والرزق والصلاح. }
$$

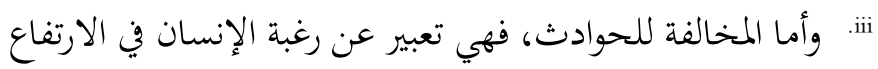
عن كل ما هو زائل وعارض ومادي وفاسد، وينتهي القول بالمخالفة للحوادث إلى التأليه، و تأليه الأشخاص دليل آخر على أن صفات الله هي في حقيقتها صفات الإنسان الكامل الذي

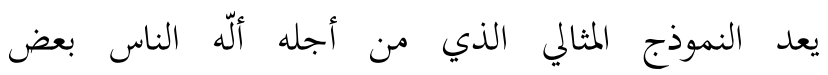
الأشخاص.

iv الاستقلال عن الحوادث، واكتفائه منها، وعدم اعتماده عليها

$$
\text { في وجوده. }
$$

وأما التوحيد، فهو عملية وليس وصفًا لشيء قائم، عملية تحدف . v إلى تحقيق الوحدانية في النفس والشعور والشخصية والمجتمع، والوحدانية في المجتمع تعني: بجتمعًا بلا طبقات، أو الوحدانية في الإنسانية.

${ }^{88}$ Ibid., 2:142.
${ }^{89}$ Ibid., 2:148.
${ }^{90}$ Ibid., 2: 239.
${ }^{91}$ Ibid., 2: 325. 
Abdullah Awad, "Hermenuitics of Creed Issue," Afkār Vol. 19 Issue 2 (2017):

وتستمر هذه التأويلات لتنال من شهادة الإسلام (لا إله إلا

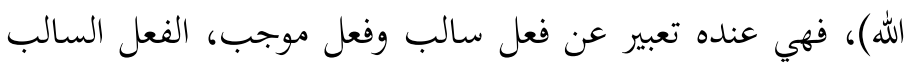

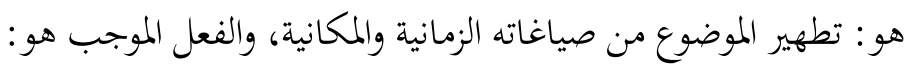
الوقوف عند إحدى هذه الصياغات باعتبارها تعبيرًا عن فعل الشعور

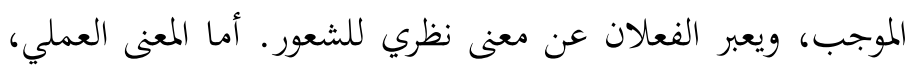

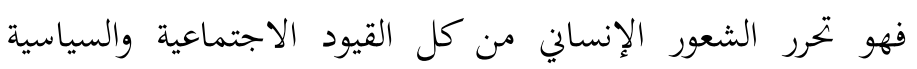
والمادية.

ويظهر مما سبق أن التصور الذي تعطيه المناهج التأويلية في مفهوم قضايا الألوهية هو في الواقع تطبيق عملي لمبادئ الهرمنيوطيقا الأساسية؛

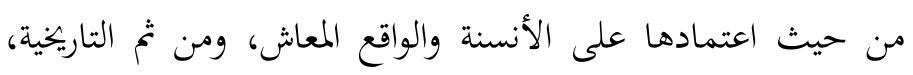
حيث تصورات الذات الإلهية ليست في الحقيقة تصورات غائية، بل

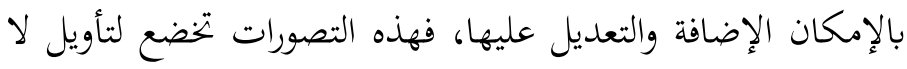
هائي حسب متطلبات الإنسان والواقع، وهو تصريح بلازم الهرمنيوطيقا ولا غائية تأويلاتما.

\section{المبحث الثالث :هرمنيوطيقا قضايا النُبوَّات}

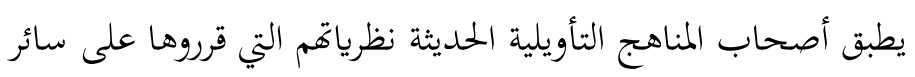

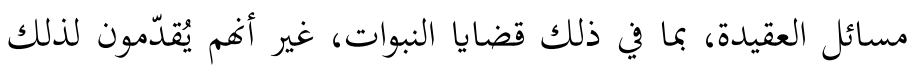
بمحاولة تعتيم مفاهيمها، والزعم بعدم وضوحها في خطوة تسبق تأويلها والتصرف بمعانيها، ومن ذلك قول بعضهم عن مفهوم النبوة والرسالة

${ }^{92}$ Ibid., 2:330. 
Abdullah Awad, "Hermenuitics of Creed Issue," Afkār Vol. 19 Issue 2 (2017):

والوحي: "من أعسر ما يتصدى له الباحث"، ويعلل ذلك بكون

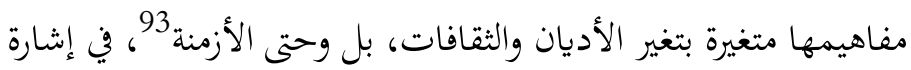

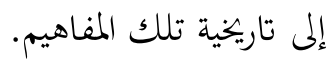
ولذا لا نكاد نجد عندهم مفهومًا علمئًا واضحًا لمذه القضايا، وإنما مجرد عبارات وإشارات تصور جانبًا معيًّا من جوانبها، وتصرفها

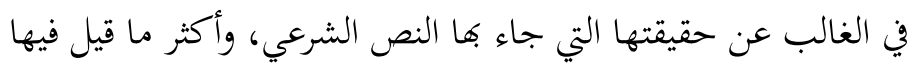
كان واردًا في ثنايا موضوعات الوحي والنص والدين والتراث وغيرها، وتوضيح ذلك كما يلي:

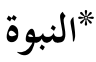

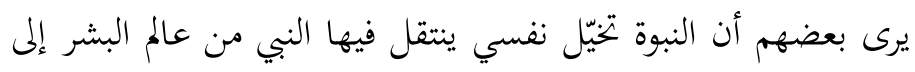

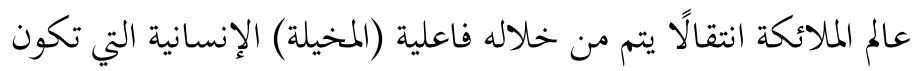

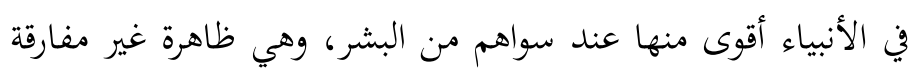

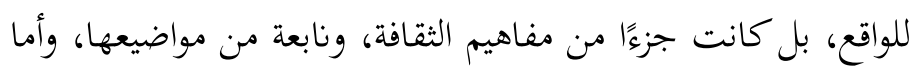

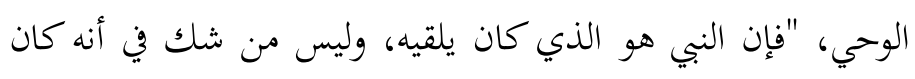

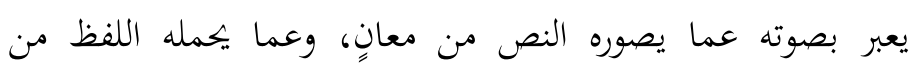

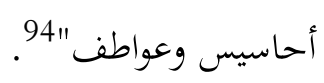

93 'Abd al-Majīid al-Sharafīi, al-Islām Bayn al-Risālah wa al-Tārìkh (Beirut: Dar al-Rafidayn, 2016), 16.

94 `Abd al-Majìd al-Sharafî, al-Islām wa al-Hadāthah (Tunisia: al-Dār al-Tunisian li al-Nashr, 1999), 88. 
وهذا التقرير في حقيقته مستفاد من كلام المستشرقين الذين قالوا بما يسمى (الوحي النفسي)"95، وزعموا أن الوحي عبارة عن إلهام كان يفيض من نفس النبي الموحى إليه لا من الخارج، ذلك أن منازع نفسه العالية، وسريرته الطاهرة، وقوة إيمانه بالله وبوجوب عبادته وترك ما سواها من عبادة وثنية وتقاليد وراثية رديئة، يكون لما في جملتها من التأثير ما يتجلى في مخيلته وذهنه، ويحدث فيها من الرؤى والأحلام والخيالات ما

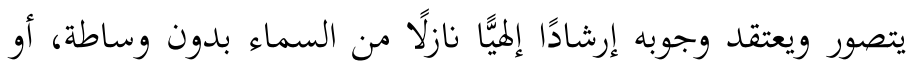
يتمثل له رجل يلقنه ذلك ويعتقد أنه ملك من عالم الغيب، أو يرى ويسمع مثل ذلك في المنام الذي هو مظهر من مظاهر الوحي عند جميع الأنبياء.

ويرى البعض الآخر منهم أن النبوة امتداد لبعض أوضاع العرب والجاهلية، وأها تواصل لحلقات الشعر والكهانة والعرافة ومختلف أشكال اتصال الإنسان بالجن، والتي كانت معروفة عند هؤلاء، ولهذا قالوا عن النبي (صلى الله عليه وسلم) بأنه شاعر وكاهن، ويعني ذلك أهم اعتبروا النبوة أمرًا عاديًا، وأوهموا الناس بذلك من أجل إلغاء آثار النبوة. 97

${ }^{95}$ See: Riyāẹ al-`Amrì, Manāhij al-Mustashriqìn wa Mawāqifihim min al-Nabì (Saudi Arabia: Markaz al-Tasīil li al-Dirāsāt, 2015), 2: 598.

يعتبر المستشرق الفرنسي (إميل درمنغم) (E. Dremenghem) من أكثر المستشرقين إثارة لهذه

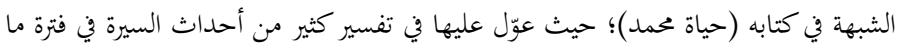

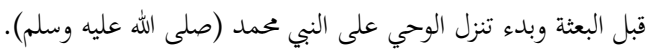

${ }^{96}$ Muhammad Rashìd Rị̣ā, al-Wahy al-Muhammadī (Beirut: Dār alKuttāb al-'Ālamì, 2005), 59.

${ }^{97}$ See: Nașr Hāmid Abū Zayd, Mafhūm al-Naș: Dirāsah fí 'Ulūm alQur'ān (Dar al-Bayḍā': n.p, 2000), 26; Kāmil al-Najjār, Qirā'ah 
Abdullah Awad, "Hermenuitics of Creed Issue," Afkār Vol. 19 Issue 2 (2017):

وهذه الدعوى - أيضًا - مأخوذة من كلام بعض المستشرقين الذين زعموا أن النبي (صلى الله عليه وسلم) قد استقى جزءًا من مادة الوحي من المصادر الجاهلية، وقد حصر هؤلاء هذه المصادر في الشعائر والعبادات والأشعار والكهانة الجاهلية، ومنهم من جعل الحنيفيّة التي كان عليها بعض الجاهليين الذين بقوا على ملة إبراهيم مصدرًا من مصادر الدين الإسلامي.

وأما محمد أركون، فيحاول أن يستعين بالتحليل التاريخي والأنثروبولوجي في معرفة ماهية النبوة ليقرر أها: "عملية إنتاج للرجال العظام 99، كما ويمكن اعتبارها بمثابة انبثاق للأبطال الحضاريين داخل فئات اجتماعية معينة، ولكن الفرق بين النبي وبين هؤلاء الأبطال الحضاريين هو أنه يستخدم أدوات ثقافية مختلفة، ويحرك النوابض النفسية

Manhajiyyah li al-Islām (Libya: Talat li al-Tiba`ah wa al-Nashr, 2015), 68.

98 See: Schacht and Bosworth, Turāth al-Islām, trans. Muhammad alSamhūrì (Kuwait: `Alam al-Ma`rifah, 1978), 3:10; Riyāḍ al-`Amrī, Manāhij al-Mustashriqīn, 2: 667.

وي مثل هذا يقول المستشرق الألماني شاخت (Schacht) عن الشريعة الإسلامية: "فهي تشتمل على عناصر من شرائع العرب في الجاهلية، وعناصر عديدة مأخوذة من شعوب البلاد التي فتحها المسلمون". وأما ما يتعلق بمصدرية أشعار العرب، فأشهر من تكلم في ذلك المستشرق الفرنسي كليمان هوارت (C. Hurt)؛ حيث زعم أنه اكتشف مصدرًا جديدًا من مصادر القرآن، يريد بذلك أشعار أمية بن الصلت.

على حد تعبير عالم الإنثربولوجيا الفرنسي موريس غودلييه. 99 
Abdullah Awad, "Hermenuitics of Creed Issue," Afkār Vol. 19 Issue 2 (2017):

الاجتماعية بشكل مميز، بمعنى أنه يعتمد على الظاهرة المعقدة للوحي

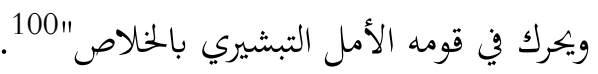

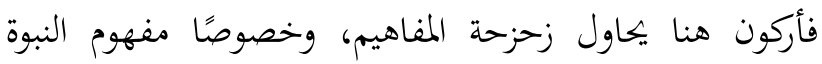

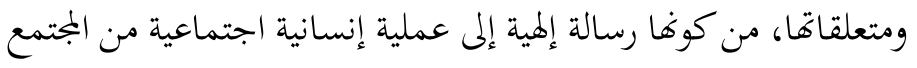

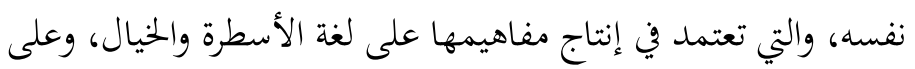

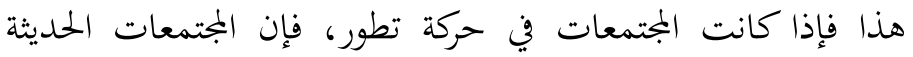

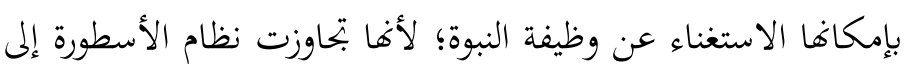
نظام العقل في إنتاج المفاهيم. وإذا كان المصدر المعرفي لهذا الخطاب هو العقل فقط، فإن

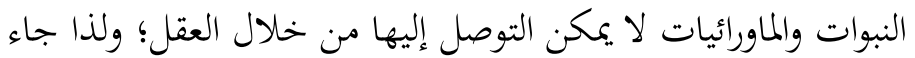

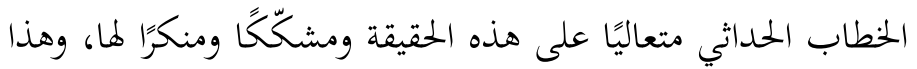
ما جعل حسن حنفي يقول: "تقوم الاستحالة العقلية على اكتفاء

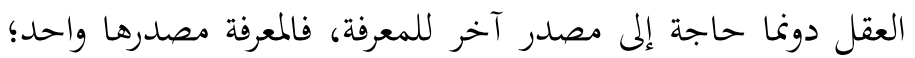

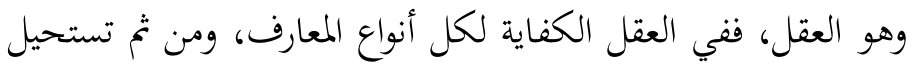

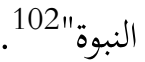

وهذا يعني أن الخطاب الحداثي يؤسس إنكاره للنبوة على العقل، وها،

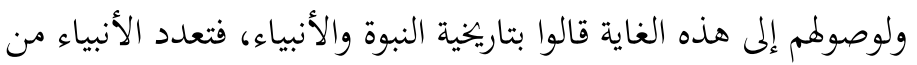

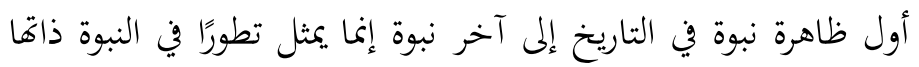

${ }^{100}$ Arkoun, Min Fayșal al-Tafriqah, 61.

${ }^{101}$ Khālid al-Sayf, Zāhirah al-Ta'wīl, 314.

${ }^{102}$ Hasan Hanafï, Min al-`Aqìdah ilā al-Thawrah, 4:42. 
Abdullah Awad, "Hermenuitics of Creed Issue," Afkār Vol. 19 Issue 2 (2017):

عبر التاريخ، "فأولو العزم من الرسل ليسوا فقط أنبياء زعماء ورسلًا

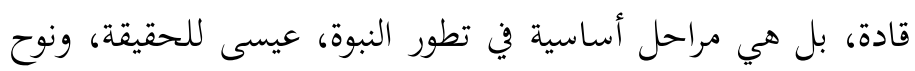

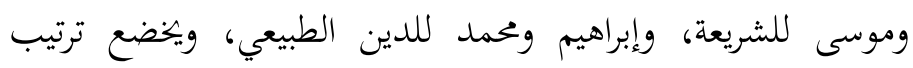

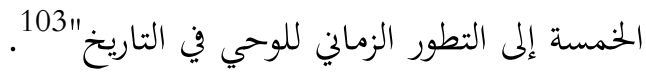

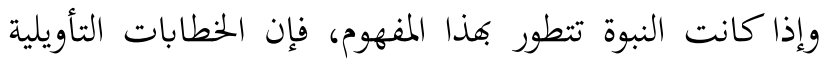
بعمومها تضفي على النبوة صبغة تاريخية، فيكون بذلك ختم النبوة دليلاً

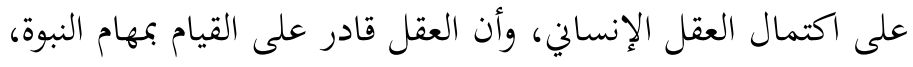
وهذا ما يقرره عبد المجيد الشرفي بقوله: "إن هذا الختم يضع حلَّا فهائيَّا لضرورة اعتماد الإنسان على مصدر في المعرفة ومعيار في السلوك مستمدين من غير مؤهلاته الذاتية ... إنه تدشين لمرحلة جديدة في التاريخ لا يحتاج فيها الإنسان وقد بلغ سن الرشد إلى من يقوده، وإلى

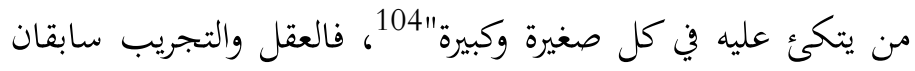

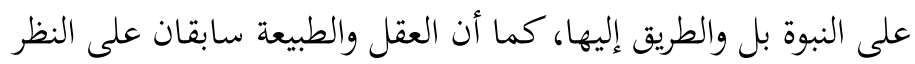
إلى الله والطريق إليه. 105

وعند التدقيق نجد أن هذه الأقوال قريبة جأًا مما قرره سبينوزا في إليه.

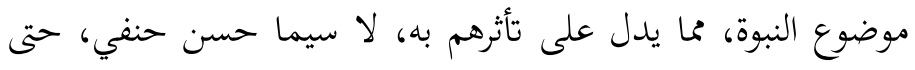

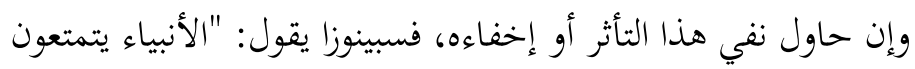

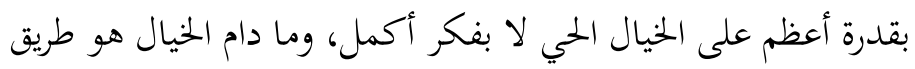

103 Ibid., 4: 109.

104 Al-Sharafī, al-Islām Bayn al-Risālah wa al-Tārīkh, 91; Khālid alSayf, Zāhirah al-Ta'wīl, 315.

${ }^{105}$ Hasan Hanafi, Min al-`Aqìidah ilā al-Thawrah, 4: 33. 
Abdullah Awad, "Hermenuitics of Creed Issue," Afkār Vol. 19 Issue 2 (2017):

الأنبياء إلى الوحي، فإغم لا يكصلون على اليقين بالوحي ذاته، وإنما

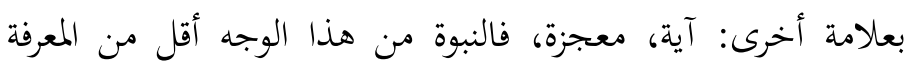

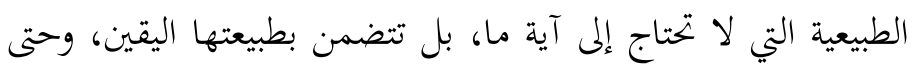

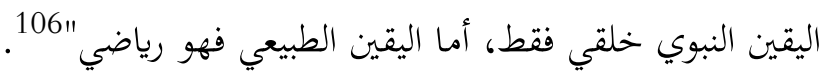

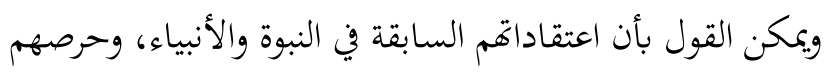
على تورخة وأنسنة هذه المفاهيم سببه أغم لو قالوا بأها من القضايا

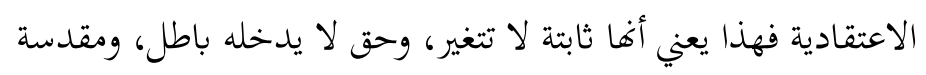

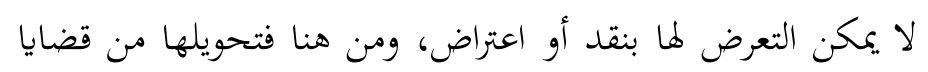

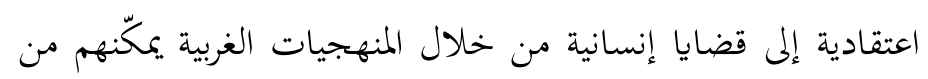
نقدها والتشكيك فيها، وتمتد هذه المواقف إلى الوحي الناتج عنها.

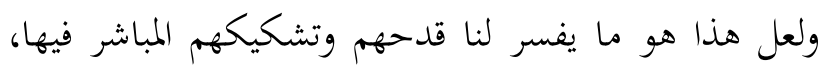

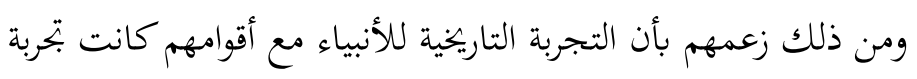
فاشلة كما يقول كامل النجار: "وأظن المنطق يقنعنا أن بتربة إرسال كل هؤلاء الأنبياء إلى بني إسرائيل كانت بتحربة فاشلة"

\section{الرسالة}

يعتبر الخطاب الحداثي الرسالة ظاهرة تاريخية لم يخاطب بها الإنسان

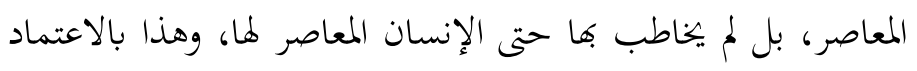
على المخاطب الثاني، وهو الجماعة التي كان يخاطبها النبي (صلى الله

\footnotetext{
106 Baruch Spinoza, Risālah fī al-Lāhūt wa al-Siyāsah, trans, Ḥasan Hanafī (Beirut: Dār al-Tanwīr, 2005), 147.

${ }^{107}$ Kāmil al-Najjār, Qirā'ah Manhajiyyah, 39.
} 
Abdullah Awad, "Hermenuitics of Creed Issue," Afkār Vol. 19 Issue 2 (2017):

عليه وسلم) مباشرة. أما الذين جاءوا من بعد وفاته واطلعوا على رسالته، فهؤلاء لا يخاطبون بها؛ لأغم في زمان غير زمانه وغير زمان الرسالة التي جاء بها؛ ولذلك حينما يتحدثون عن النبي (صلى الله عليه وسلم) يقولون بأنه: "مسؤول بحكم وظيفته هذه عن الرسالة وبحسيدها في التاريخ عن طريق انخراط شخص ثالث هو المرسل إليه الجماعي" "108. وبناء على القول بتاريخية الرسالة، ذهب بعضهم إلى اعتبار العبادات الشرعية غير مستمرة على النحو الذي فصلته السنة النبوية،

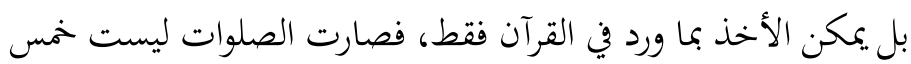
صلوات في اليوم والليلة، بل يمكن أن تكون مرة واحدة، وليس لها عدد

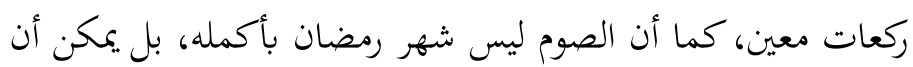
يكون يومًا أو أيامًا متفرقة استنادًا لما جاء في القرآن فحسب، وأما الزكاة فلم تبق - أيضًا - على الصورة المشروعة، والحج إنما شرع لاجتماع المسلمين، فمتى تحقق ذلك لم يعد واجبًا، وهكذا في سائر المسائل التي كانت السنة هي الموضحة لما. 109 وإذا كان الأمر كما سبق تقريره بأن ختم النبوة - عندهم - دليل على اكتمال العقل الإنساني، وأن العقل قادر على القيام بمهام النبوة، فهذا يعني أنه لم يعد للرسالة حاجة، ذلك أن اكتمال النبوة يعني انتهاءها، وإذا انتهت النبوة فقد انتهت الرسالة، وهذا يعني إعطاء

108 Arkoun, al-Fikr al-Islāmī, 94.

109 Al-Sharafī, al-Islām Bayn al-Risālah wa al-Tārìkh, 49-88; Marzūq al'Umarī, Ishkāliyyah Tārìkhiyyah al-Naș al-Dīnì (Rabat: al-Markaz alThaqafï al-`Arabi, 2014), 404. 
Abdullah Awad, "Hermenuitics of Creed Issue," Afkār Vol. 19 Issue 2 (2017):

الإنسان ثقة بالنفس وفرصة للفعل، فاكتمالها معناه أن تربية الوحي

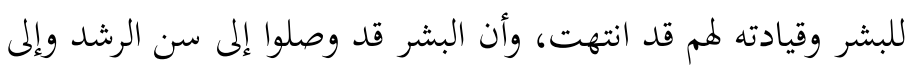

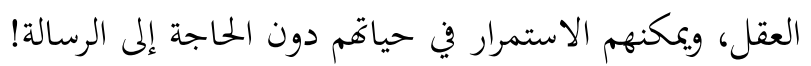
وبذلك يكون النبي محمد (صلى الله عليه وسلم) - في اعتقادهم - قد ختم النبوة والرسالة ليقضي على التكرار والاجترار، وليفتح المجال

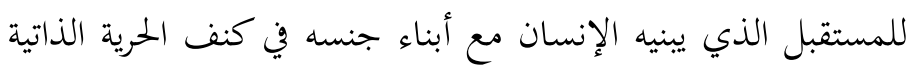
والمسؤولية الفردية والتضامن الخلاق. 110

\section{"المعجزة}

تفاوتت عبارات أصحاب هذا الخطاب في تحديد موقفهم من

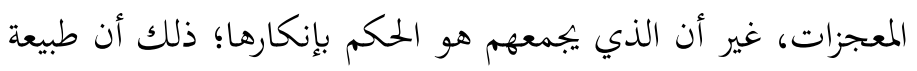

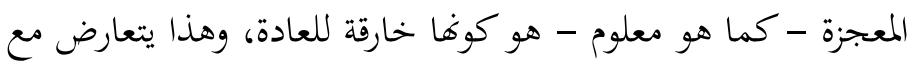

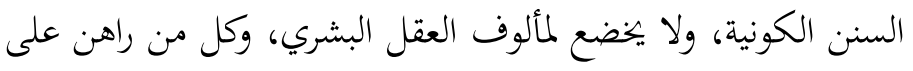

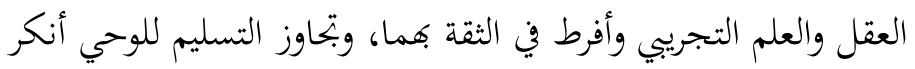
المعجزات أو سعى في تأويلها. 111

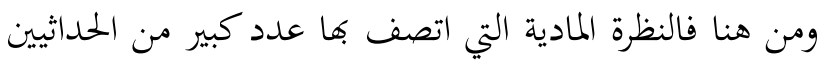

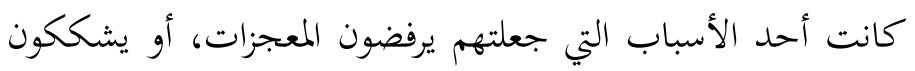
فيها، باعتبارها خرجت عن إطار المادية والتجريبية، ولا توافق قانون

${ }^{110}$ Al-Sharafī, al-Islām Bayn al-Risālah wa al-Tārìkh, 93.

111 Mājid al-Asmarī, al-'Ilmāniyyūn wa al-Nubuwwah (Saudi Arabia: Markaz Takwin, 2015), 143. 
Abdullah Awad, "Hermenuitics of Creed Issue," Afkār Vol. 19 Issue 2 (2017):

السببية112، كما أنه يلزم من التصديق بها القول بجهل الإنسان وعجزه أمام الطبيعة، وأن الكون سرٌّ مغلق لا يمكن الدخول فيه. 113 فالمعجزات - عندهم - قدح في العقل، وإنكار لبديهيات العقول، كما أها إنكار لقوانين الطبيعة، وهي في النهاية من فعل الأجسام بطباعها، وليس خرقًا لقوانينها، وتحدث طبقًا للطبائع وليس قلبًا لها، فقوانين الطبيعة ثابتة لا تخرق بفعل أحد، وإن خرقها لأدل على النفي منه على التصديق، وأدعى إلى زعزعة الثقة بالعقل وبالعلم منه إلى إعطاء معرفة أو تصديق بديل، فقوانين الطبيعة وخواص الأشياء تمنع من التصديق بالمعجزة. 114 ويحاول بعضهم 115 أن يربط المعجزة بالأساطير والخزافات، فيزعم أن المعجزة ارتبطت في التاريخ البشري بالأسطورة والخرافة، وقصص الخوارق؛ كالسحر والشعوذة وأحاديث العجائب والغرائب، وأها من تأليف الأنبياء والرسل الذين وظّفوا بعض القوانين الطبيعية لإيهام الناس بأغم مرسلون من الله تعالى. ولذا لا نستغرب من تلك المحاولات التي سعت إلى أسطرة سيرة الرسول (صلى الله عليه وسلم)، كما فعل جورج طرابيشي عند كلامه عن السيرة الحلبية، فذكر أها "قد استفادت من كل التراجم من أدبيات

112 Nūr al-Dīn Mukhtār al-Khādimí, al-Qirā'ah al-Ta'wìiyyah li alQur'ān al-Karìm Bayn al-Tabdìd wa al-Tajdìd (Damascus: Dār alGhūthānī, 2014), 191.

${ }^{113}$ Hasan Ḥanafï, Min al-`Aqìdah ilä al-Thawrah, 4: 65.

114 Ibid., 4: 78.

${ }^{115}$ Ramzì Ibrāhìm, al-Mufassir wa al-Naș, 529. 
السيرة لترقى بعملية الأسطرة إلى مستوى غير مسبوق، ولتحيط بهالتها

$$
\text { الرسول قبل مبعثه وبعده"116. }
$$

وكذلك فعل محمد أركون في مواضع من كتبه عند كلامه عن

منهج ابن إسحاق وابن هشام في سيرتيهما؛ إذ يقول: "فقد استخدمت المبالغات الحيالية والشعبية بشكل غير متمايز من حيث الدلالة والحقيقة عن العناصر التي نصنفها بالتاريخية ضمن رؤيتنا الحديثة للمعرفة،

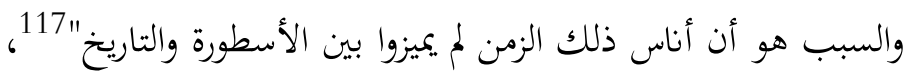
بل يتهم جيل ابن إسحاق كاملًا بالوقوع في ترويج الأسطورة، فيقول: "ينغي أن نأخذ بالاعتبار تلك الحياة الأسطورية لجيل ابن إسحاق الذي راح يجوّر من شخصية النبي" ل118. ثم إن التصديق بالمعجزة في حقيقة الأمر طريق إلى الإقرار بالمقدس، وتدعيم النبوة والرسالة، وترسيخ قيم الوحي ومحتواه الإنساني والاجتماعي والحضاري، وهو الأمر المرفوض عند أصحاب هذا

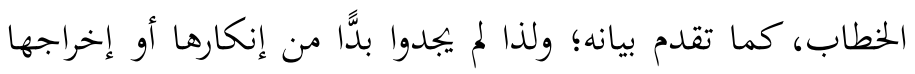
عن معانيها وحقائقها التي جاء بها النص الشرعي، وإن حاول بعضهم تفسيرها تفسيرا علميَّا 119.

${ }^{116}$ George Tarabishi, Sabāt al-`Aql fī al-Islām (Beirut: Dār al-Saqī,n.d), 77.

117 Arkoun, al-Fikr al-Islāmi, 75.

118 Ibid., 79; Mājid al-Asmarì, al-`Ilmāniyyūn wa al-Nubuwwah, 146.

119 Muhammad 'Ābid al-Jabrí, Madkhal ilā Fahm al-Qur'ān al-Karīm (Beirut: Markaz Dirāsah al-Wiḥdah al-`Arabiyyah, 2006), 189. 
Abdullah Awad, "Hermenuitics of Creed Issue," Afkār Vol. 19 Issue 2 (2017):

وعند تأمل هذه الأقوال نجد أنها في الواقع امتداد - أيضًا - لما

قاله الغربيّون والمستشرقون في حق الأنبياء ومعجزاهم، فهذا سبينوزا يقول: "لا وجود للمعجزات، ولا يحدث شيء يناقض الطبيعة، فالطبيعة تحتفظ بنظام أزلي لا يتغير، والقوانين العامة للطبيعة ليست إلا بجرد أوامر إلهية تصدر عن ضرورة الطبيعة الإلهية وكمالها، فلو حدث شيء في الطبيعة يناقض قوانينها العامة كان هذا الشيء مناقضًا أيضًا لأوامر الله وعقله وطبيعته؛ لأن قوة الطبيعة وقدرةا هي قوة الله وقدرته، وقوانين الطبيعة هي أوامر الله ذاته"120.

وأما المستشرق الفرنسي غوستاف لوبون (Gustave Le Bon)، فيقول: "ولم يقل محمد إنه يأتي بالخوارق مع إيمانه برسالته، وعزا المسلمون إليه خوارق كثيرة بجاراة للعنعنات الشائعة القائلة إنه لا نبوة بغير خوارق" 121، كما أن عددًا منهم اجتهل في نفي أو تأويل معجزات النبي (صلى الله عليه وسلم) المادية كمراد هوفمان وبوسورث سميث ودرمنغم وغيرهم.

\section{المبحث الرابع :هرمنيوطيقا قضايا السمعيّات}

ينكر أصحاب النزعة الهرمنيوطيقية أي معرفة خارج نطاق الإنسان (الحس)، ذلك أن اعتمادهم في إدراك المعارف - كما سبق - على العقل والحواس، فلا شيء فوق الإنسان وعالمه المحسوس؛ ولذا فهم لا

${ }^{120}$ Spinoza, Risālah fī al-Lāhūt wa al-Siyāsah, 222.

${ }^{121}$ Gustave Le Bon, Haḍārah al-`Arab, trans. `Adil Zaytir (Cairo: al-Dār al-Mișriyyah, n.d), 113. 
Abdullah Awad, "Hermenuitics of Creed Issue," Afkār Vol. 19 Issue 2 (2017):

يتحرجون من إنكار الغيبيات التي وردت في الوحي وجاء بها الدين

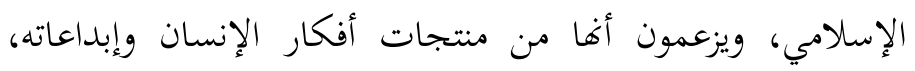
والأولى - عندهم - أن توضع هذه القضايا في خانة الأساطير

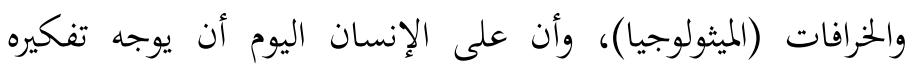
واهتمامه إلى عالم الدنيا، ويترك كل أمر ججهول لا وجود له في واقعه. 122

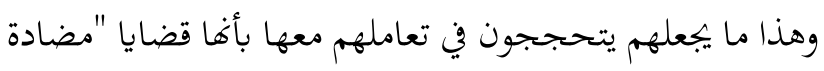

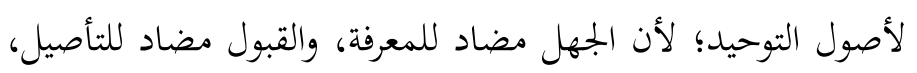

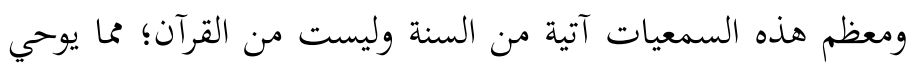

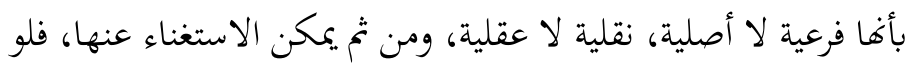

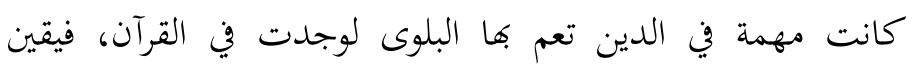

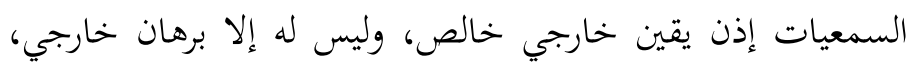

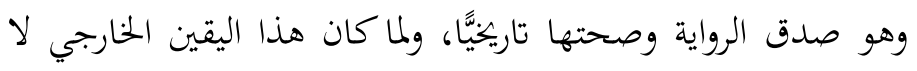

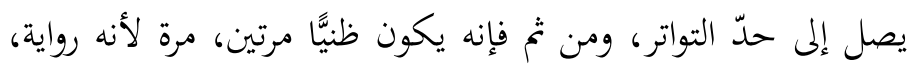
وأخرى لأنه خبر آحاد لا تعطي السمعيات يقينًا نظريَّا"

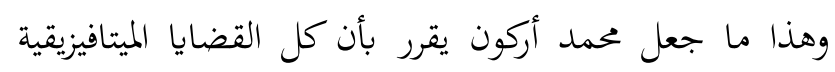

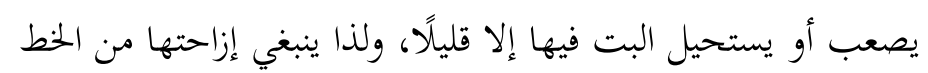
التاريخي الذي يجبرنا العقل الأدواتي البراغماتي على اتباعه. 124

${ }^{122}$ Al-Nu`aymì, al-Qirā'ah al-Hadāthiyyah, 257.

${ }^{123}$ Hasan Hanafī, Min al- 'Aqìiah ilā al-Thawrah, 4: 425.

124 Arkoun, al-Fikr al-Ușūlì, 123. 
Abdullah Awad, "Hermenuitics of Creed Issue," Afkār Vol. 19 Issue 2 (2017):

وأما حسن حنفي، فيرى أن الغيبيات لا بد أن تؤول معانيها بأمور حسية مشاهدة، فألفاظ الجن والملائكة والشياطين، بل والخلق والبعث والقيامة، كلها ألفاظ تجاوز الحس والمشاهدة ولا يمكن استعمالها؛ لأهما لا تشير إلى واقع ولا يقبلها كل الناس، وكذلك الميزان والصراط والأعراف والحوض ومنكر ونكير، وكل ما أطلق عليه العلماء القدماء (سمعيات) لا تشير إلى حس ومشاهدة إلا عن طريق تأويل معاني الألفاظ، واستعارة الألفاظ الحسية للدلالة بها على معالٍ إنسانية.

ويشكك عبد المجيد الشريف في هذه الغيبيات ويرى أها ليست إلا رموزًا وأمثالًا لا حقائق ها، "وأن المنهج في القراءة هو الكفيل بالحفاظ على مصداقية رسالة الإسلام على اختلاف أوضاع المسلمين، واعتبارًا للغاية الكامنة وراء حديث القرآن عن آدم وحواء، وعن إبليس والجن والشياطين والملائكة، وعن معجزات الأنبياء، لا يضير المؤمن أن يرى في كل هذا الذي ينتمي إلى الميثية رموزًا وأمثالًا لا حقائق تاريخية"126 . ويرى أن الأصل في هذه المضامين أنها موجهة إلى أناس معيّنين في زمن معيّن تتناسب مع ثقافتهم، وأها مستمدة من الظواهر الميثالوجية التي تبدو اليوم بعيدة عن المفاهيم والتصورات الحديثة. 127

${ }^{125}$ Hasan Hanafī, al-Turāth wa al-Tajdid, 121.

126 Al-Sharafī, al-Islām Bayn al-Risālah wa al-Tārīkh, 61.

127 Ibid., 45; Sulaymān al-Ghusn, I'ādah Qirā'ah al-Naș al-Shar’ $\bar{i} w a$ Istihdāfihi fí al-Fikr al-`Arabì al-Mu āṣir (Riyadh: Dār Kunūz, 2016), 404. 
Abdullah Awad, "Hermenuitics of Creed Issue," Afkār Vol. 19 Issue 2 (2017):

والواقع أن أصحاب هذا الخطاب يتعاملون مع النصوص الشرعية التي جاءت صريحة في الدلالة على هذه القضايا تعاملاً ماديًّا، مستخدمين في ذلك ما أنتجته الفلسفة الغربية من المناهج التاريخية والاجتماعية والمادية وغيرها من أجل رفع المفهوم الشرعي عنها،

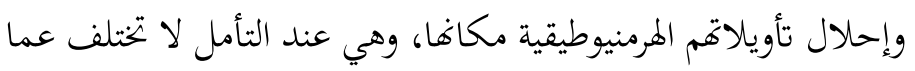
قررته الهرمنيوطيقا الغربية، وتفصيل ذلك كما يلي:

\section{"املائكة}

يتعامل أصحاب هذا الخطاب مع الوجود الحقيقي للملائكة على أنه

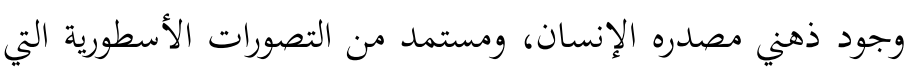
تنشأ في ذهنية المجتمع في ظروف دهني خاصة، وهذان وها التعامل امتداد للهرمنيوطيقا الرومانسية التي أسسها شلاير ماخر، والتي يلزم منها تغيّر المعنى ولا غائية التأويل. 128

يقول حسن حنفي عن الملائكة: هي "أسماء تعبر بدلالاتما على ولى

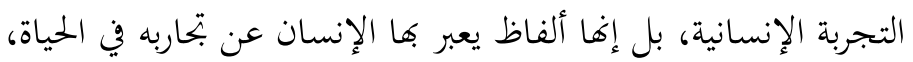

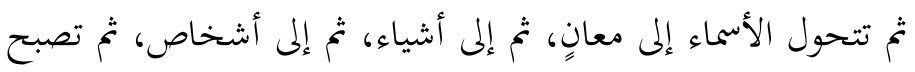

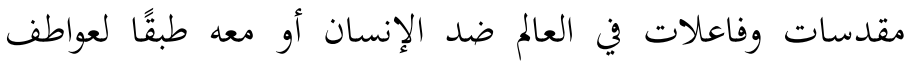
الإيجاب والسلب وانفعالات الخير والشر"

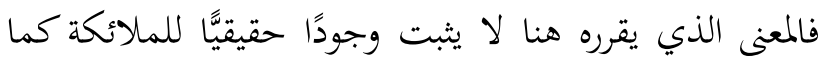
جاء في النصوص الشرعية وكما يؤمن به المسلمون، وهو كما نلاحظ

${ }^{128}$ Khālid al-Sayf, Zāhirah al-Ta'wìl, 322.

${ }^{129}$ Hasan Hanafî, Min al- Aqìidah ilà al-Thawrah, 4: 409. 
Abdullah Awad, "Hermenuitics of Creed Issue," Afkār Vol. 19 Issue 2 (2017):

ينكر هذه القضايا ويؤولها معتمدًا على العقل بإسقاطها على حياة

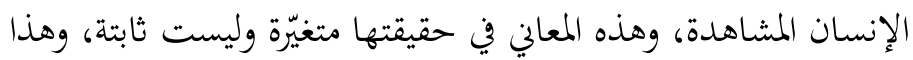
التغيّر لا غاية له كما سبق.

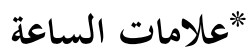

ما دام أفم لا يؤمنون - كما تقرر سابقًا - إلا بالعقل والتجربة، ولا لاعهات

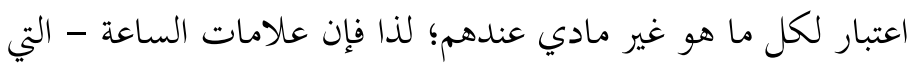
جاءت بما النصوص الشرعية صريحة وواضحة، وهي في غالبها جزء من لن

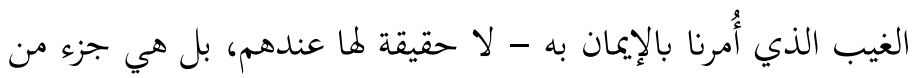
الخيال الشعبي الذي تأثر بالديانات السابقة كاليهودية والنصرانية. يقول حسن حنفي عنها: هي "من الخيال الشعبي، والتي تنبئ بحوادث آخر الزمان - كما هو معروف في كل الأخرويات - تعويضًا

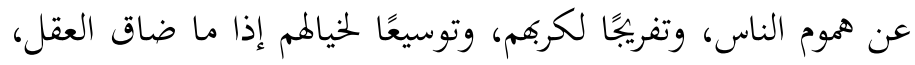

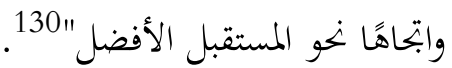
وحجته في ذلك أن هذه العلامات لا وجود لشيء منها في أصل أصل الوحي، وهناك علامات أخرى في أصل الوحي ليست منها، وإنما جاءت علامات الساعة في علم العقائد من روايات ضعيفة وضعها

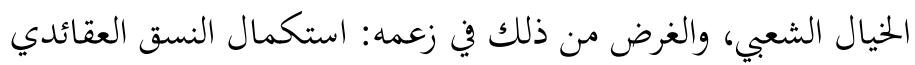

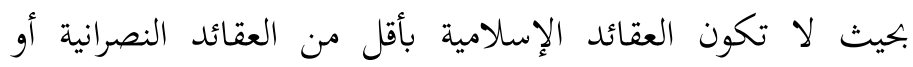

${ }^{130}$ Ibid., 4: 468. 
Abdullah Awad, "Hermenuitics of Creed Issue," Afkār Vol. 19 Issue 2 (2017): 143-204

اليهودية، كما أنه لا يمكن بتربتها أو التحقق من صدقها لا عقلًا ولا تجربة؛ لأفها لم تحدث بعدُ ولم يرها أحد. 131

\section{"امعاد*}

يجري الحداثيون قواعدهم التأويلية السابقة في التعامل مع نصوص المعاد

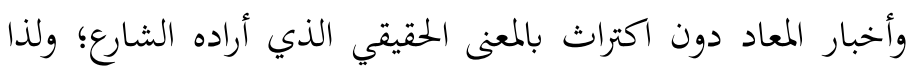

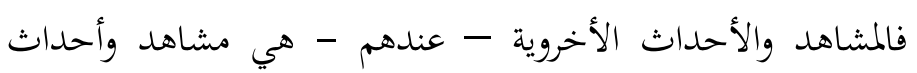

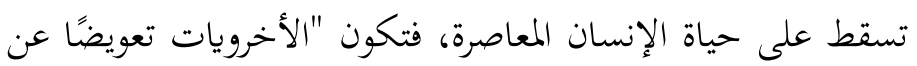

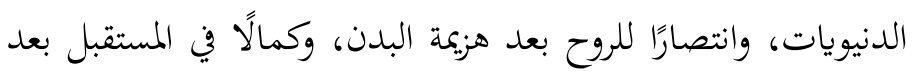
ازدياد الكرب في الحاضر" "132.

ويتحججون في نفيها أو تأويلها بكوها - أيضًا - روايات

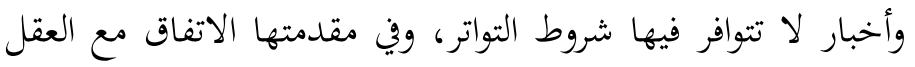

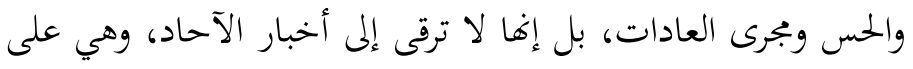

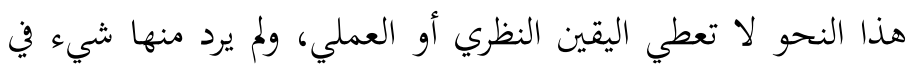
أصل الوحي الأول، وهو القرآن. 133

وينفي حسن حنفي أن يكون البعث واقعة مادية، وحوادث

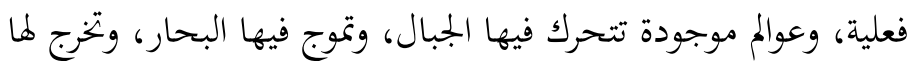

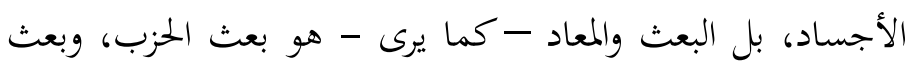
الأمة، وبعث الروح، وهذا يعني أنه واقعة شعورية، وبواعث سلوكية، ئرئ

${ }^{131}$ Ibid., 4: 549 \& 528.

132 Ibid., 4: 460.

133 Ibid., 4: 461. 
Abdullah Awad, "Hermenuitics of Creed Issue," Afkār Vol. 19 Issue 2 (2017):

ودوافع للفعل للتأثير على السلوك، والحث على الطاعة؛ ترغيبًا تارة وترهيًا أخرى، فهو في الحقيقة في هذه الدنيا لا في دنيا أخرى مفارقة.

وفي موضع آخر يذكر أن أمور المعاد في أحسن الأحوال تصوير فنيٌّ يقوم به الخيال تعويضًا عن حرمان في الخبز أو الحرية، في القوت أو

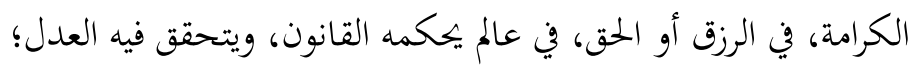
لذلك تظهر باستمرار في فترات الاضطهاد وفي لحظات العجز، وحين يسود الظلم ويعم القهر كتعويض عن عالم مثالي يأخذ فيه الإنسان 135

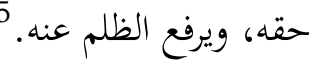
وما دام أنه لا حقيقة للمعاد عندهم، فإنه ليس هناك إلا دنيا واحدة وآخرة واحدة هي نفسها الدنيا، والجنة والنار المذكورة هما النعيم والعذاب في هذه الدنيا، وليس في عالم آخر يحشر فيه الإنسان بعد الموت، فالدنيا هي الأرض، والعالم الآخر هو الأرض أيضًا، والجنة هي ما يصيب الإنسان من خير في الدنيا، والنار ما يصيب الإنسان من شر فيها. 136 ونلاحظ في تأويلاتم هذه اعتمادها على المنهج المادي الإنسي المتأثر بلا شعوريات فرويد في موضوع الأديان 137، فغاية قضية المعاد عندهم صورة فنية أوجدها الخيال الشعبي في فترات خاصة، وما زالت

${ }^{134}$ Ibid., 4: 508 \& 599.

135 Ibid., 4: 600.

${ }^{136}$ Ibid., 4: 601.

${ }^{137}$ Khālid al-Sayf, Zāhhirah al-Ta'wìl, 326. 
Abdullah Awad, "Hermenuitics of Creed Issue," Afkār Vol. 19 Issue 2 (2017):

تتطور حسبما تقتضيه نظرية الهرمنيوطيقا، وتبعًا لتغيّر المجتمعات، وهي في النهاية أحكام قيم وليست أحكام وقائع.

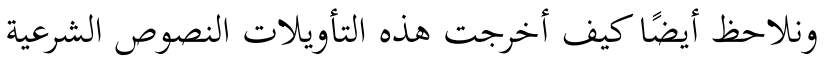
وما تضمنته من قضايا يقينيّة عن معانيها التي جاء بها جميع الأنبياء

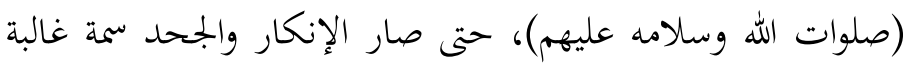

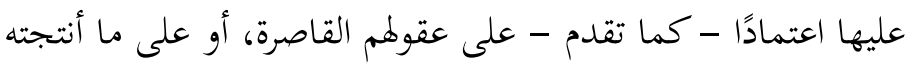

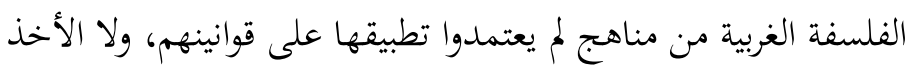
مها في تعاملاقم.

\section{الخاتمة}

وفي خاتمة هذا البحث، أذكر أهم النتائج التي توصلت إليها:

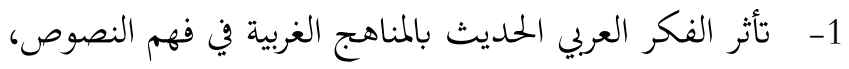
حتى تكوّن ما يمكن تسميته بالهرمنيوطيقا العربية. 2- استخدم أصحاب هذا الخطاب القراءة التاريخية لرفع وبتحوز ما يعتقده المسلمون في القرآن باعتباره أحكامًا أزلية ثابتة.

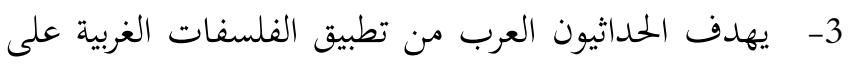

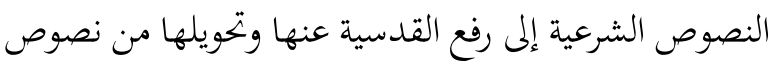
إلهية إلى نصوص بشرية، ونفي مقاصدها العقدية والمنلقية والتربوية. 
Abdullah Awad, "Hermenuitics of Creed Issue," Afkār Vol. 19 Issue 2 (2017):

4- الأنسنة العربية لا تختلف كثيرًا عن نظيرتا الغربية من حيث معارضتها للأديان السماوية، ورفضها الارتباط العلوي لأي

$$
\text { مفهوم أو معرفة. }
$$

5- تدعم النظريات الحديثة للتأويل بغالب أطيافها ومناهجها القول بأن العقائد التي تؤسسها النصوص الشرعية متغيرة ضرورة وليست ثابتة، من أجل بتحاوز الفكر الديني التقليدي

$$
\text { إلى فكر ديني جديد. }
$$

6- التصور الذي تعطيه المناهج التأويلية في مفهوم قضايا الألوهية

هو في الواقع تطبيق عملي لمبادئ الهرمنيوطيقا الأساسية. 7- يؤسس الخطاب الحداثي إنكاره للنبوة على العقل. 8- تحويلهم القضايا الاعتقادية إلى قضايا إنسانية من خلال المنهجيات الغربية يمكّنهم من نقدها والتشكيك فيها، وتمتد هذا المواقف إلى الوحي الناتج عنها. 9- النظرة المادية التي اتصف بها عدد كبير من الحداثيين كانت أحد الأسباب التي جعلتهم يرفضون الغيبيات لإنكارهم أي معرفة خارج نطاق الإنسان. 10- العلاقة الواضحة بين ما قره أصحاب هذا الخطاب وبين ما قاله المستشرقون والمفكرون الغربيون، والتي تصل إلى حدّ

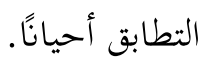




$$
\begin{aligned}
& \text { 11- أخرجت هذه التأويلات النصوص الشرعية وما تضمنته من } \\
& \text { قضايا عقدية عن معانيها التي جاء بها جميع الأنبياء (صلوات } \\
& \text { الله وسالامه عليهم). } \\
& \text { 12- لا تختلف الهرمنيوطيقا العربية عن نظيرتا الغربية في الاعتماد } \\
& \text { على المناهج التاريخية والاجتماعية والمادية. }
\end{aligned}
$$

\section{References}

'Abd al-Raḥmān, Ṭahā. Fiqh al-Falsafah. Dār al-Bayḍā': Al-Markaz al-Thaqāfī al-'Arabi, n.d.

'Abd al-Raḥmān, Țaha. Rūh al-Hadāthah. Dār al-Bayḍā': Al-Markaz al-Thaqafī al-`Arabì, 2006.

Abū Zayd, Nașr Hāmid. Al-Naș wa al-Sulțah wa alHaqīqah Irādah al-Ma rifiyyah wa Irādah al-Himanah. Dār al-Bayḍā': al-Markaz al-Thaqafīi al-'Arabì, 2006.

Abū Zayd, Nașr Hāmid. Ishkāliyyāt al-Qirā'ah wa Āliyāt al-Ta'wìl. Beirut: al-Markaz al-Thaqāfī al-'Arabī, 2014.

Abū Zayd, Nașr Ḥāmid. Mafhūm al-Naṣ: Dirāsah fì 'Ulūm al-Qur'ān. Dār al-Bayḍ̄à': n.p, 2000

Abū Zayd, Nașr Hāmid. Naqd al-Khițāb al-Dīnī. Dār alBayḍ̄à': Al-Markaz al-Thaqafi al-`Arabī, 2007.

Al-'Amrī, Riyāḍ. Manāhij al-Mustashriqīn wa Mawāqifihim min al-Nabì. Saudi Arabia: Markaz alTa'sīl li al-Dirāsāt, 2015.

Arkoun, Muhammad. Al-Fikr al-Islāmì Qirā'ah 'Ilmiyyah, trans. Hashīm Șālih. Beirut: Dār al-Saqī, 1991.

Arkoun, Muḥammad. Al-Fikr al-Ușūli wa Istiḥālah alTa 'ṣill, trans. Hashīm Șāliḥ. Beirut: Dar al-Saqi, 2002. Arkoun, Muḥammad. Al-Qur'ān min al-Tafsìr al-Mawrūth ila Tahlìl al-Khițāb al-Dìni, trans. Hashìm Sālīh. Beirut: Dar al-Tali'ah, 2005.

Arkoun, Muhammad. Min al-Ijtihād ila Naqd al-`Aql alIslāmī, trans. Hashīm Ṣāliḥ. Beirut: Dar al-Saqī, 1991. 
Arkoun, Muhammad. Min Fayṣal al-Tafriqah ila Fasl alMaqāl: Ayna Huwa al-Fikr al-Islāmī, trans. Hashìm Șāliḥ. Beirut: Dar al-Saqi, 1995.

Arkoun, Muhammad. Qad̄aya fí Naqd al-`Aql al-Dīní, trans. Hashìm Șālih. Beirut: Dar al-Tali'ah, 2004.

Arkoun, Muhammad. Tārīkhiyyah al-Fikr al-Islāmì, trans. Hashīm Șāliḥ. Beirut: al-Markaz al-Thaqāfî̀ al-`Arabí, 1996.

Al-Asmarī, Mājid. Al-`Ilmāniyyūn wa al-Nubuwwah. Saudi Arabia: Markaz Takwin, 2015.

Al-`Awawdah, Rā'id. Falsafah al-Ta'wīl al-Tārikhì. Jordan: `Ālam al-Kutub al-Hadithah, 2016.

Al-`Aẓm, Șādiq Jalāl. Naqd al-Fikr al-Dīnī. Beirut: Dār alTali'ah, 2003.

Bāhì, Yāsīn. Al-Ta'wīl wa Falsafah al-Tawāṣul. Jordan: alKutub al-Hadith, 2016.

Balqiz, `Abd Allāh. Naqd al-Turāth. Beirut: Markaz Dirāsah al-Wiḥdah al-`Arabiyyah, 2016.

Brenton, Crane. Tashkīl al-`Aql al-Hadìth, trans. Shawqī ‘Allam. Kuwait: `Ālam al-Ma`rifah, n.d.

Al-Ghusn, Sulaymān. I'ādah Qirā'ah al-Naș al-Shar 'ì wa Istihdāfihi fì al-Fikr al-`Arabì al-Mu'āṣir. Riyadh: Dār Kunūz, 2016.

Al-Hafnī, `Abd al-Mun `im. Al-Mu’jam al-Falsafi. Cairo: al-Dār al-Sharqiyyah, 1990.

Hanafī, Hasan, "al-Hermeneuțiqā wa 'Ulūm al-Ta'wìl," Majallah Qaḍ̂yā Islāmiyyah Mu'āṣarah, vol. 19.

Hanafī, Hasan. Min al-`Aqìdah ilā al-Thawrah. Cairo: Maktabat al-Madbult, 1988.

Hanz, Ghādmīr. Falsafah al-Ta'wìl, trans. Muhammad Shawqi al-Zayn. Beirut: Manșūrah, 2000.

Harb, 'Alì. Naqd al-Naș. Dār al-Bayḍā': al-Markaz alThaqāfí al-`Arabi, 2005.

Al-Ḥusaynī, Muhammad 'Alì. Abistemūlūjiyā al-Ta'wìl.

Beirut: Dār al-Rafīidayn, 2016. 
Ibrāhīm, Zakariyyā. Mushkilāt Falsafiyyah Mu'āṣarah (Mushkilah al-Insān). Cairo: Maktabah Mișr, n.d.

Al-Jabrì, Muhammad 'Ābid. Madkhal ilā Fahm al-Qur'ān al-Karìm. Beirut: Markaz Dirāsah al-Wiḥdah al'Arabiyyah, 2006.

Jadmir. Al-Haqiqah wa al-Manhaj, trans. Hasan Nazim and `Ali Șaliḥ. Dār `Ulya, 2007.

Al-Khādimī, Nūr al-Dīn Mukhtār. Al-Qirā'ah alTa 'wìliyyah li al-Qur'ān al-Karìm Bayn al-Tabdìd wa alTajdìd. Damascus: Dār al-Ghūthānì, 2014.

Lalande, Andre. Mawsū 'ah Lalande al-Falsafiyyah, trans. Khalī Ahmad Khalìl. Beirut: Awaydat li al-Nashr, 2012. Al-Lahāyib, Aḥmad. Mafhūm al- Ansanah: `Arḍ wa Naqd, Bahth Damn Majallah al-Dirāsāt al-Islāmiyyah, Jāmi`ah al-Malik `Abd al-Aziz, vol. 27.

Le Bon, Gustave. Haḍārah al-`Arab, trans. 'Adil Zaytir. Cairo: al-Dār al-Mișriyyah, n.d.

Muștafā. 'Ādil. Fahm al-Fahm Madkhal ila alHermeneuțiqua . Cairo: Ri`aya al-Nashr wa al-Tawzi', 2007.

Al-Najjār, 'Abd al-Majīd. Al-Qirā'ah al-Jadìdah li al-Naș al-Dìni. Damascus: Markaz al-Fikriyyah, 2006.

Al-Najjār, Kāmil. Qirā'ah Manhajiyyah li al-Islām. Libya: Țalat li al-Tiba`ah wa al-Nashr, 2015.

Al-Nu aymī, Muhammad Sālim. Al-Qirā'ah alHadāthiyyah li al-Naș al-Qur'āni. Cairo: Miṣr al'Arabiyyah li al-Nashr, 2016.

Niqāz, Ismā’ìl. Manāhij al-Ta'wì fī al-Fikr al-Ușūlì: Dirāsah Taḥlīliyyah wa Naqdiyyah Muqāranah li Manāhij al-Ta'wiliyyah al-Mu'āṣarah. Beirut: Markaz Naml li al-Buhūth wa al-Dirāsāt, 2017.

Qāsim, Sīzā. Al-Qārì' wa al-Naș. Cairo: al-Majlis al-'A'lā al-Thaqāfah, 2002.

Al-Qurashī, Fahd. Manhaj Hasan Hanafī: Dirāsah Taḥlīliyyah Naqdiyyah. Riyadh: al-Bayān, 1434H. 
Rashìd Riḍā, Muhammad. Al-Wahy al-Muhammadì. Beirut: Dār al-Kuttāb al-`Ālamī, 2005.

Ricour, Paul. Min al-Naș ila al-Fi'l Abhāth al-Ta'wìl, trans. Muhammad Barrada and Hasan Burqia. Cairo: al-Dirāsāt wa al-Buhūth al-Insāniyyah al-Ijtimā iyyah, 2001.

Rodger, Bobner. Al-Falsafah al-Almāniyyah al-Hadīthah, trans. Fu'ad Kāmil. Cairo: Dār al-Thaqāfah li al-Nashr, n.d.

Al-Sayf, Khālid. Zāhirah al-Ta'wìl al-Hadìthah fī al-Fikr al-`Arabì al-Mu'āṣir. Jeddah: Markaz al-Ta'sìl li alDirāsat, 2015.

Samīr, Hamīd. Namūzaj al-Hadāthah wa mā Ba`dahā fī alFikr al-`Arabi al-Hadith. Saudi Arabia: Markaz Takwin, 2017.

Sayyid Aḥmad, Mu'tașim. Al-Hermenuitiqā fì al-Wāqi' alIslāmì. Beirut: Dār al-Hādì, 2009.

Schacht and Bosworth, Turāth al-Islām, trans. Muhammad al-Samhūrí. Kuwait: `Alam al-Ma`rifah, 1978.

Al-Sharafī, 'Abd al-Majìd et. al. Fì Qirā'ah al-Naș al-Dīnì. Tunisia: al-Dār al-Tūnis li al-Nashr, 1990.

Spinoza, Baruch. Risālah fī al-Lāhūt wa al-Siyāsah, trans, Hasan Hanafī. Beirut: Dār al-Tanwīr, 2005.

Sharafī, 'Abd al-Karim. Min Falsafāt al-Ta'wì ila Nazariyyāt al-Qirā'ah. Beirut: al-Dār al-'Arabiyyah li al'Ulūm, n.d.

Al-Sharafī, 'Abd al-Majìd. Al-Islām Bayn al-Risālah wa alTārìkh. Beirut: Dar al-Rafidayn, 2016.

Al-Sharafī, 'Abd al-Majīd. Al-Islām wa al-Hadāthah. Tunisia: al-Dār al-Tunisian li al-Nashr, 1999.

Al-Shaykh, Muḥammad and al-Ṭā'ì, Yāsir. Muqārabāt fì al-Hadāthah wa mā ba`d al-Hadāthah. Beirut: Dār alTali'ah, 1996.

Al-Ṭa`ān, Aḥmad. Al-`Ilmāniyyūn wa al-Qur'ān al-Karīm. Riyadh: Dār Ibn Hazm, 2007.

Tarabishi, George. Sabāt al-`Aql fī al-Islām. Beirut: Dār alSaqi, n.d. 
Al-'Umarī, Marzūq. Ishkāliyyah Tārīkhiyyah al-Naṣ alDìni. Rabat: al-Markaz al-Thaqafī al-'Arabī, 2014.

Al-'Utaybī, Sa`d Bajād. Mawqif al-Ittijāh al-`Aqlānì alIslāmì al-Mu'āșir min al-Naș al-Shar'`i. Riyadh: Markaz al-Fikr al-Mu'āṣir, 1431H.

Wahbah, Murād. Al-Mu jam al-Falsafī. Cairo: Dār Qabā li al-Tiba`ah, 1998.

Wahbah, Murād. Malāk al-Haqīqah al-Muṭlaqah. Cairo: Dār Qubā, 1999.

Zāyid, Aḥmad. Al-Hermenuitiqā wa Ishkāliyyāt al-Ta’wīl. Qatar: Qatar University, 1991. 